\title{
Expanding Access to Remdesivir via an Improved Pyrrolotriazine Synthesis: Supply Centered Synthesis
}

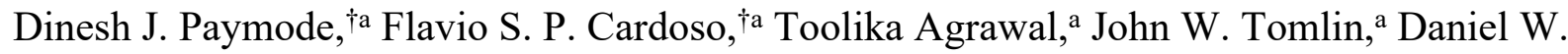
Cook, ${ }^{\mathrm{b}}$ Justina M. Burns, ${ }^{\mathrm{b}}$ Rodger W. Stringham, ${ }^{\mathrm{b}}$ Joshua D. Sieber, ${ }^{\mathrm{a}}$ B. Frank Gupton, ${ }^{\mathrm{a}}$ David R. Snead*a

Supplemental Information:

Contents

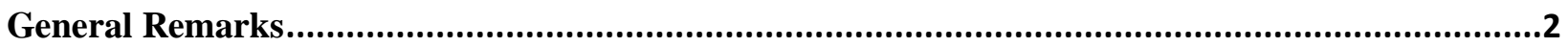

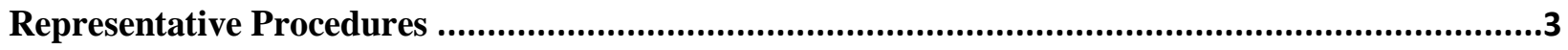

One-pot Synthesis of 2-Cyanopyrrole from Pyrrole ......................................................................6

$\mathrm{N}$-Amination of 2-Cyanopyrole Using Solid Aminating Reagents ...............................................10

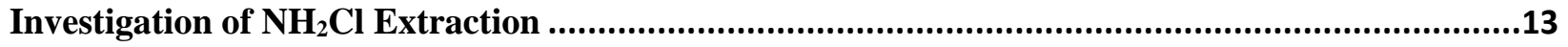

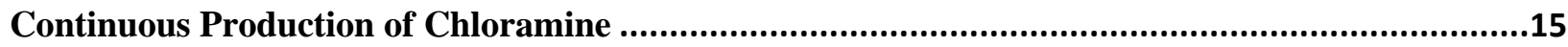

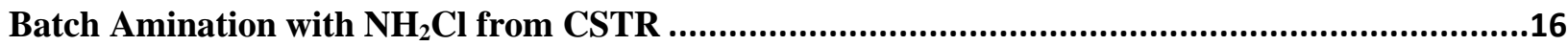

Continuous Amination in PFR with $\mathrm{NH}_{2} \mathrm{Cl}$ from CSTR .......................................................18

Batch Amination with Multicharge of Chloramine ................................................................19

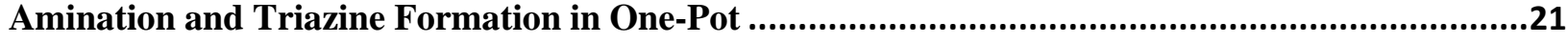

Evaluation of Alternative Bases and Solvents for Addressing Safety in the Amination step............23

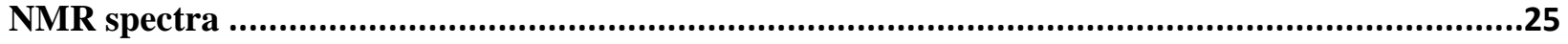

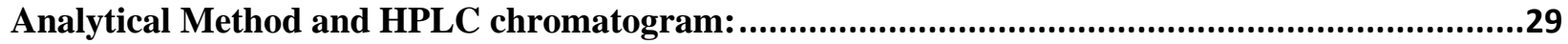

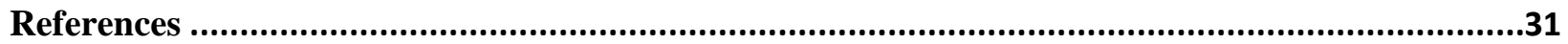




\section{$\underline{\text { General Remarks }}$}

Instrumentation: For all compounds, $\mathrm{H}$ and C NMR spectra were recorded on a Bruker Avance III 600 MHz spectrometer. Chemical shifts were measured relative to the residual solvent resonance for ${ }^{1} \mathrm{H}$ and ${ }^{13} \mathrm{C}$ $\mathrm{NMR}\left(\mathrm{CDCl}_{3}=7.26 \mathrm{ppm}\right.$ for ${ }^{1} \mathrm{H}$ and $77.2 \mathrm{ppm}$ for ${ }^{13} \mathrm{C}$, DMSO- $d_{6}=2.50 \mathrm{ppm}$ for ${ }^{1} \mathrm{H}$ and $39.2 \mathrm{ppm}$ for $\left.{ }^{13} \mathrm{C}\right)$. Coupling constants $J$ are reported in hertz $(\mathrm{Hz})$. The following abbreviations were used to designate signal multiplicity: s, singlet; d, doublet; t, triplet; q, quartet, p, pentet; dd, doublet of doublet; ddd, doublet of doublet of doublet; dt, double of triplet; ddt, doublet of doublet of triplet; m, multiplet; br, broad. Reactions were monitored by HPLC using the methods indicated. 2-Cyanopyrrole, $\mathrm{N}$-amino-2-cyanopyrrole and triazine were monitored using identical HPLC methods (see Analytical Method Section for details). Glassware was oven-dried at $120^{\circ} \mathrm{C}$, assembled while hot, and cooled to ambient temperature under an inert atmosphere. Unless noted otherwise, reactions involving air sensitive reagents and/or requiring anhydrous conditions were performed under a nitrogen atmosphere.

Reagents and solvents. Reagents and solvents were purchased from Aldrich Chemical Company, Fisher Scientific, Alfa Aesar, Acros Organics, Oakwood, or TCI. Liquid reagents were purified by distillation when necessary. Unless otherwise noted, solid reagents were used without further purification. Methylene chloride (DCM) and dimethylformamide (DMF) taken from a solid-sorbant Solvent Dispensing System purchased from Pure Process Technologies or distilled as described in the literature. 


\section{$\underline{\text { Representative Procedures: }}$}

2-cyanopyrrole (Table S2, entry 10):

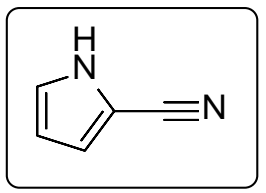

A $1 \mathrm{~L}$ three necked round bottom flask was equipped with a J-KEM internal temperature probe, overhead stirrer and nitrogen line. The flask was charged with anhydrous DMF (250 mL) and cooled to an internal temperature of $0-5{ }^{\circ} \mathrm{C}$ under an atmosphere of nitrogen. With stirring (300 RPM), phosphoryl trichloride (38.3 mL, $409.9 \mathrm{mmol}, 1.1 \mathrm{eq}$.) was slowly charged while maintaining internal temperature below $15^{\circ} \mathrm{C}$. The reaction mixture was stirred at $20^{\circ} \mathrm{C}$ for another 30 minutes. The reaction was cooled to $0-5{ }^{\circ} \mathrm{C}$ and pyrrole (25.0 g, $372.6 \mathrm{mmol}, 1.0$ eq.) was slowly charged while maintaining internal temperature below 15 ${ }^{\circ} \mathrm{C}$. The reaction mixture was stirred at $20^{\circ} \mathrm{C}$ for another $1 \mathrm{~h}$. The light brown solution was cooled to $0-5$ ${ }^{\circ} \mathrm{C}$ and water $\left(75 \mathrm{~mL}\right.$ ) was added while maintaining internal temperature below $15{ }^{\circ} \mathrm{C}$. The reaction was stirred for 5 minutes at same temperature. Solid hydroxylamine hydrochloride (28.48 g, $409.9 \mathrm{mmol}, 1.1$ eq.), acetic anhydride ( $38.7 \mathrm{~mL}, 409.9 \mathrm{mmol}, 1.1$ eq.) and pyridine ( $150 \mathrm{~mL}, 1.863 \mathrm{~mol}, 5.0$ eq.) were added sequentially, the internal temperature was not allowed to exceed $15{ }^{\circ} \mathrm{C}$. After the addition was complete, the reaction mixture was heated to $90{ }^{\circ} \mathrm{C}$ (heating block) for overnight (16 hours). After complete consumption of the iminium chloride salt, as indicated by ${ }^{1} \mathrm{H} \mathrm{NMR}$, the reaction mixture was diluted with water $(250 \mathrm{~mL})$ and transferred to the separating funnel. The product was extracted from dark brown reaction mixture by using ethyl acetate (3 X $400 \mathrm{~mL}$ ). The combined organic layer was washed with $1 \mathrm{M}$ $\mathrm{HCl}(250 \mathrm{~mL})$ and brine $(250 \mathrm{~mL})$, dried over sodium sulfate and concentrated using rotary evaporation under reduced pressure. The desired 2-cyanopyrrole (34.7 g, 90\% (adjusted with 89\% purity by HPLC)) was distilled out from dark brown oil under vacuum at $100-140^{\circ} \mathrm{C}$. The obtained product was used for next (amination) step (52 g CSTR batch; in Batch Amination with $\mathrm{NH}_{2} \mathrm{Cl}$ from CSTR section).

${ }^{1} \mathbf{H}$ NMR of intermediate iminium chloride salt (600 MHz, DMSO- $\left.d_{6}\right) \delta 13.52$ (br s, $\left.1 \mathrm{H}\right), 9.03(\mathrm{~s}, 1 \mathrm{H}$ ), 7.49 - 7.50 (m, 1H), $7.17-7.17$ (m, 1H), $6.53-6.54$ (m, 1H) ppm.

${ }^{1} \mathbf{H}$ NMR of 2-cyanopyrrole (600 MHz, DMSO- $\left.d_{6}\right) \delta 12.29$ (br s, 1H), $7.13-7.15$ (m, 1H), $6.89-6.91$ (m, 1H), $6.21-6.23(\mathrm{~m}, 1 \mathrm{H}) \mathrm{ppm} .{ }^{13} \mathrm{C}$ NMR of 2-cyanopyrrole (150 MHz, DMSO-d $\left.{ }_{6}\right) \delta 125.1,119.9$, 115.4, 110.0, 100.0 ppm. Data match those previously reported. ${ }^{1}$

\section{Pyrrolotriazine (Table S6, Entry 4):}

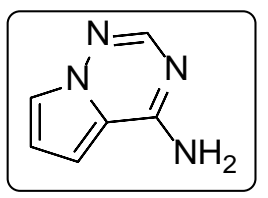

Monochloramine Synthesis (0.74M in MTBE): 
$\mathrm{NH}_{4} \mathrm{Cl}$ (24.6 g) in MTBE (330 mL) was cooled to $-5{ }^{\circ} \mathrm{C}$ (internal temperature) in a 2L-round bottom flask, and concentrated $\mathrm{NH}_{4} \mathrm{OH}$ (38.4 mL) was added. Sodium hypochlorite (10-15\% solution, Sigma-Aldrich, $432 \mathrm{~mL}$ ) was then added via addition funnel over $30 \mathrm{~min}$. The mixture was stirred for $30 \mathrm{~min}$, the layers were separated, and the organic layer was washed with brine $(1 \times 180 \mathrm{~mL})$. The organic layer was dried over powdered $\mathrm{CaCl}_{2}(15 \mathrm{~g})$ in the freezer for at least $1 \mathrm{~h}$ and kept at the same temperature. Approximate concentration is $0.74 \mathrm{M}$.

A $0.5 \mathrm{~L}$ three necked round bottom flask was equipped with a J-KEM internal temperature probe and a stirring bar. A solution of $1 H$-pyrrole-2-carbonitrile (10.0 g, $105.3 \mathrm{mmol}, 97 \%$ purity) in MTBE (100 mL) was added, cooled in an ice bath (internal temperature between $\left.5-10{ }^{\circ} \mathrm{C}\right)$ and $\mathrm{NaH}(6.3 \mathrm{~g}, 158.0 \mathrm{mmol}, 60 \%$ in mineral oil Sigma-Aldrich) was added in portions. The reaction was stirred for $30 \mathrm{~min}$ at room temperature. DMF (50 mL) was added and MTBE was distilled under vacuum at $20-30{ }^{\circ} \mathrm{C}$ (internal temperature). Chloramine in MTBE (170 mL, $125.8 \mathrm{mmol}, 0.74 \mathrm{M}$ solution) was added. The reaction was monitored by HPLC until conversion is $>95 \%$ (less than 30 minutes). To the reaction mixture was added formamidine acetate (32.89 g, $315.9 \mathrm{mmol}$, 99\% Chem-Impex). The mixture was heated while distilling MTBE at atmospheric pressure until internal temperature reaches $90-95{ }^{\circ} \mathrm{C}$ (heating block). The reaction was stirred at the same temperature for 16 hours. Assay ${ }^{1} \mathrm{H}$ NMR using 1,3,5-trimethoxybenzene as internal standard showed $75 \%$ assay yield to triazine. The mixture was concentrated through distillation under vacuum (40-45 mL of DMF was recovered) and $100 \mathrm{~mL}$ of water was added washing the vessel walls. The flask was placed in an ice-bath and the internal temperature was monitored until it reached $\sim 5{ }^{\circ} \mathrm{C}$. The mixture was filtered and washed with $20 \mathrm{~mL}$ of water. The brown solids were transferred to $250 \mathrm{~mL}$ round bottom flask, dried under vacuum and $100 \mathrm{~mL}$ of MTBE was added. The mixture was vigorously stirred until a uniform suspension is observed. The suspension was filtered giving the triazine as a brown powder which was dried under vacuum (8.53 g, 99.0\% purity by HPLC, $60 \%$ yield).

${ }^{1}$ H NMR (600 MHz, DMSO-d $\left.d_{6}\right) \delta$ 7.66-8.01 (m, 3H), 7.61 (s, 1H), 6.91 (s, 1H) 6.61 (s, 1H); ${ }^{13}$ C NMR $\left(151 \mathrm{MHz}, \mathrm{DMSO}-d_{6}\right) \delta 155.7,148.1,118.2,114.2,110.2,101.5$. Data match those previously reported. ${ }^{2}$

\section{Alternative amination replacing DMF with diglyme: Synthesis of 1-amino-1H-pyrrole-2-carbonitrile (Table S7, Entry 3):}

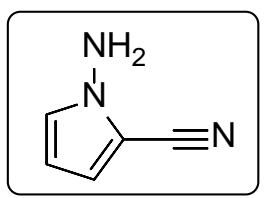

To a solution of $1 H$-pyrrole-2-carbonitrile ( $400.0 \mathrm{mg}, 4.34 \mathrm{mmol}$ ) in diglyme (4 mL) was added NaH (261.0 mg, $3.257 \mathrm{mmol}, 60 \%$ in mineral oil Sigma-Aldrich), and the reaction was stirred for $30 \mathrm{~min}$ at room temperature. $\mathrm{NH}_{2} \mathrm{Cl}$ (16 mL, ca. $0.56 \mathrm{M}$ in MTBE) was added via syringe. After $1 \mathrm{~h}$ (97\% assay yield), the reaction mixture was passed through Celite, washed with ethyl acetate and solvent was removed under reduced pressure at $80{ }^{\circ} \mathrm{C}$. The crude product was obtained as a brownish oil (603 mg, $65 \%$ purity, $84 \%$ yield). The mixture was subjected to column chromatography using ethyl acetate and hexanes as eluent solvents $(5 \% \rightarrow 25 \%)$. The pure fractions were concentrated to give the required product as a pale-yellow oil (220 mg, 98\% purity, $47 \%$ yield).

${ }^{1} \mathbf{H}$ NMR (600 MHz, CDCl $) \delta 6.95(\mathrm{~s}, 1 \mathrm{H}), 6.72(\mathrm{~d}, J=4.1 \mathrm{~Hz}, 1 \mathrm{H}), 6.08(\mathrm{~d}, J=3.6 \mathrm{~Hz}, 1 \mathrm{H}), 4.41$ (br s, 2H) ppm. ${ }^{13} \mathrm{C}$ NMR (150 MHz, $\left.\mathrm{CDCl}_{3}\right) \delta$ 128.1, 117.7, 113.4, 107.1, 105.4 ppm. Data match those previously reported. ${ }^{2}$ 
${ }^{1} \mathrm{H}$ NMR spectrum of 1-amino-1H-pyrrole-2-carbonitrile in $\mathrm{CDCl}_{3}$ at $600 \mathrm{MHz}$ :

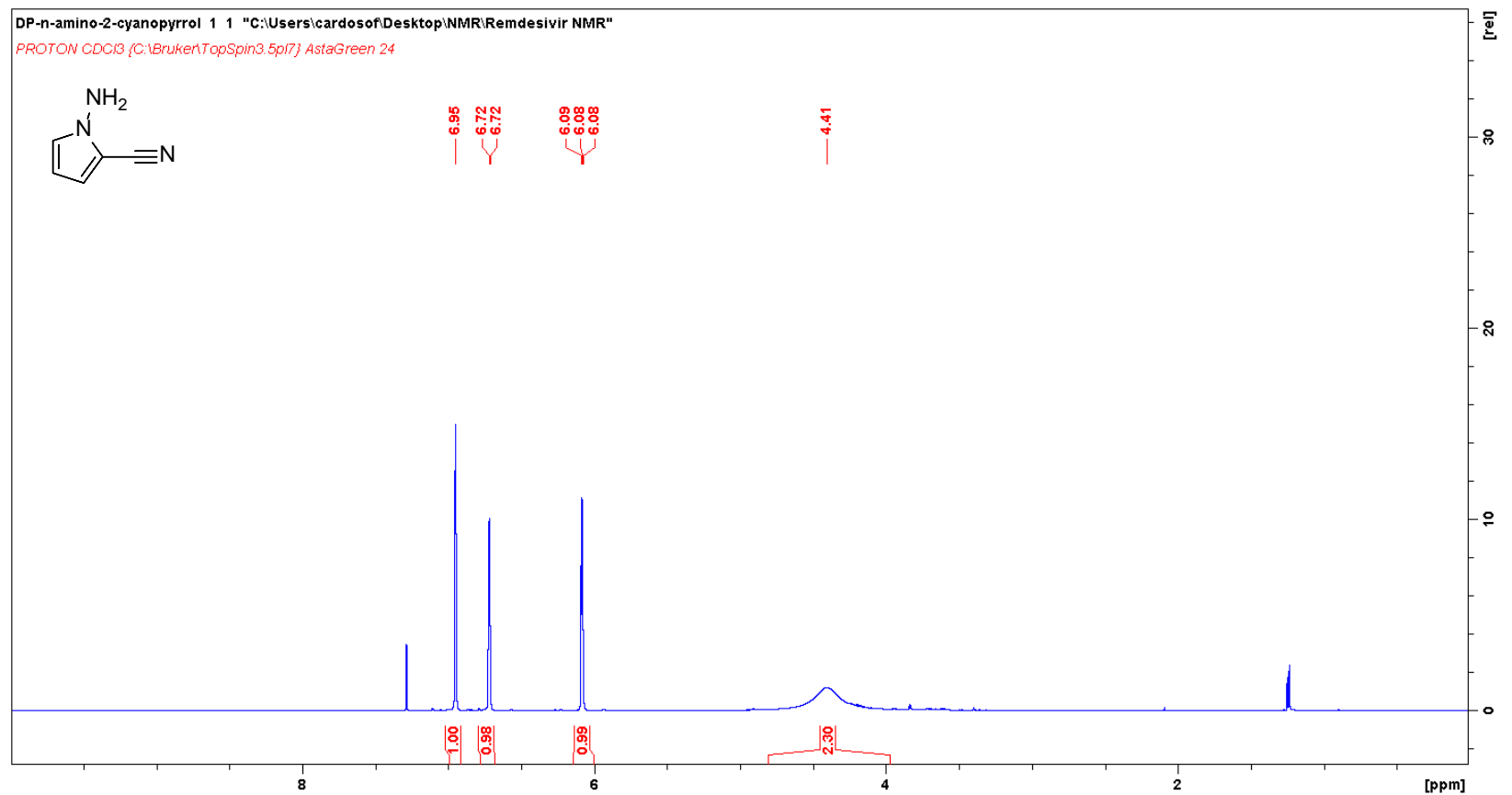

${ }^{13} \mathrm{C}$ NMR spectrum of 1-amino- $1 \mathrm{H}$-pyrrole-2-carbonitrile in $\mathrm{CDCl}_{3}$ at $151 \mathrm{MHz}$ :

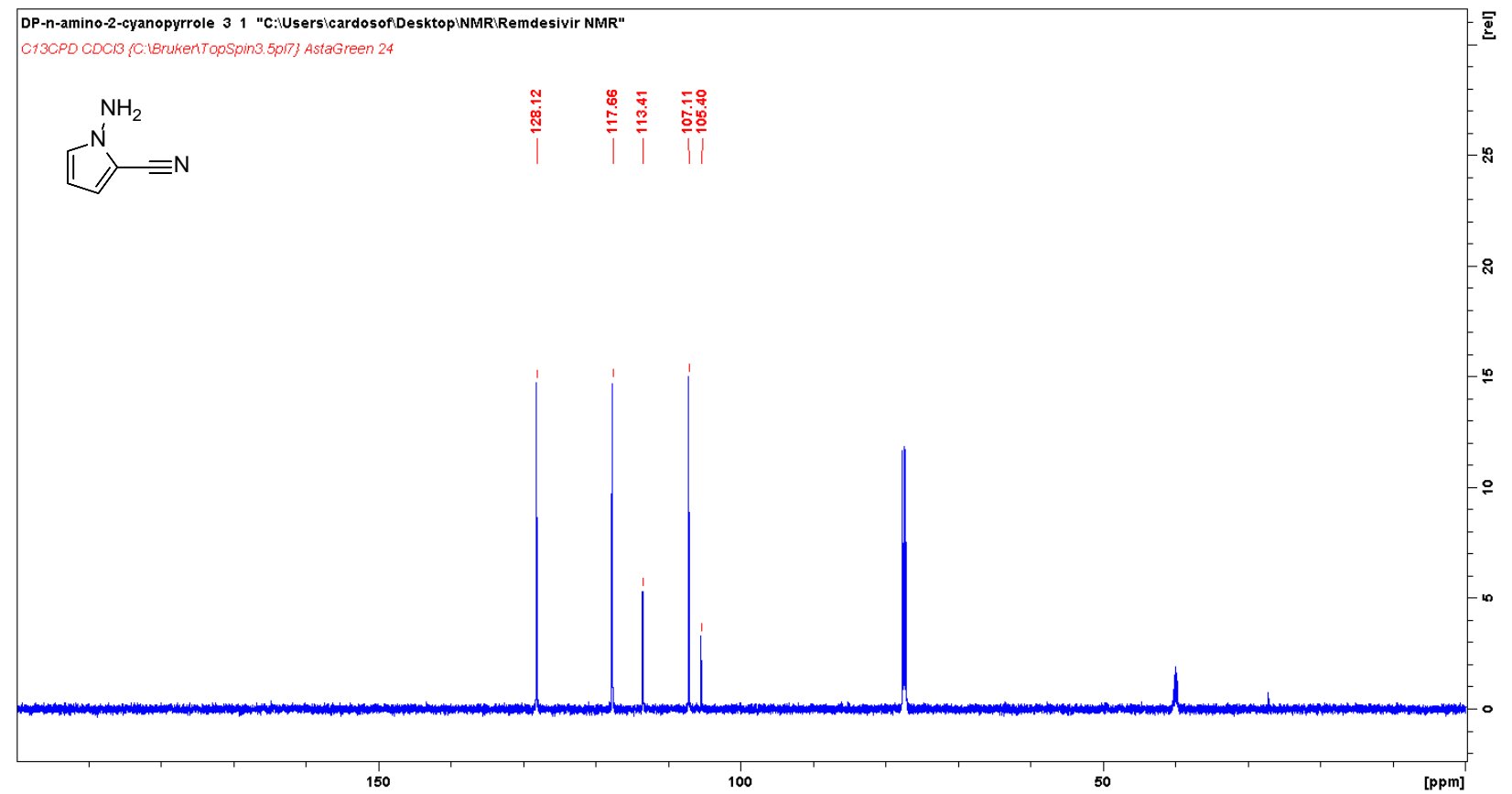




\section{One-pot Synthesis of 2-Cyanopyrrole from Pyrrole}

Table S1: Optimization for synthesis of 2-cyanopyrrole from pyrrole under acidic conditions.

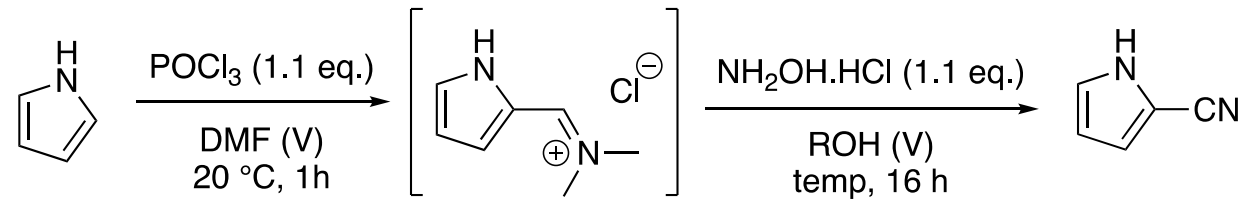

\begin{tabular}{|c|c|c|c|c|c|c|}
\hline Entry & Scale (g) & Solvent (V) & ROH (V) & Temp. $\left({ }^{\circ} \mathbf{C}\right)$ & AY (\%) & $\begin{array}{c}\text { IY (Purity) } \\
\text { (\%) }\end{array}$ \\
\hline 1 & 0.5 & DMF (15) & - & 125 & 58 & - \\
\hline 2 & 0.2 & DMF (10) & - & 90 & 25 & - \\
\hline 3 & 0.2 & DMF (10) & $\mathrm{H}_{2} \mathrm{O}(3)$ & 90 & 78 & - \\
\hline 4 & 0.2 & DMF (10) & $\mathrm{EtOH}(3)$ & 90 & 84 & - \\
\hline 5 & 0.25 & DMF (10) & $\mathrm{H}_{2} \mathrm{O}(3)$ & 80 & 74 & - \\
\hline 6 & 0.25 & DMF (10) & $\mathrm{H}_{2} \mathrm{O}(5)$ & 80 & 61 & - \\
\hline 7 & 0.25 & DMF (10) & $\mathrm{H}_{2} \mathrm{O}(10)$ & 80 & 51 & - \\
\hline 8 & 0.25 & DMF (15) & $\mathrm{H}_{2} \mathrm{O}(3)$ & 80 & 74 & - \\
\hline 9 & 0.25 & DMF (15) & $\mathrm{H}_{2} \mathrm{O}(5)$ & 80 & 94 & $72(72)$ \\
\hline 10 & 0.25 & DMF (15) & $\mathrm{H}_{2} \mathrm{O}(10)$ & 80 & 47 & 93 \\
\hline 11 & 25 & DMF (15) & $\mathrm{H}_{2} \mathrm{O}(5)$ & 80 & 93 & - \\
\hline
\end{tabular}

The synthesis began with C-2 formylation of pyrrole and further its oxidation to nitrile. Both reactions are well known in literature, however, 2-formyl pyrrole is a low melting solid not easily distilled or recrystallized in good yield. Moreover, waste will be generated in the process of purifying the aldehyde, aldoxime or other intermediates. We wondered whether isolation of the aldehyde or aldoxime intermediate was necessary. Both reactions can be performed in same solvent, the iminium chloride salt could be used directly to form the nitrile in one-pot. Considering this, we began our efforts with formylation of pyrrole using $\mathrm{POCl}_{3}$ (1.1 eq.) in DMF (15V) (Table S1, entry 1). The complete conversion of pyrrole to iminium chloride salt was observed in $1 \mathrm{~h}$, analyzed by ${ }^{1} \mathrm{H}$ NMR. According to the literature, ${ }^{1}$ the oxidation of 2formylpyrrole to 2-cyanopyrrole is feasible at higher temperature $\left(125^{\circ} \mathrm{C}\right)$. Keeping this in mind, the hydroxylamine hydrochloride (1.1 equiv.) was added to the reaction mixture and heated at $125{ }^{\circ} \mathrm{C}$ for $16 \mathrm{~h}$ (overnight). The reaction was dark and sluggish, however, gave $58 \%$ assay yield by ${ }^{1} \mathrm{H}$ NMR (mesitylene was used as internal standard). Further, the assay yield dropped to $25 \%$ by lowering the reaction temperature to $90{ }^{\circ} \mathrm{C}$ (Table S1, entry 2). The lower yields could be because of chemical incompatibility of hydroxylamine hydrochloride with residual $\mathrm{POCl}_{3}$ and related species which would need to be quenched. Thus, water or ethanol was added to the reaction mixture prior to addition of hydroxylamine hydrochloride. 
The $\mathrm{HCl}$ generated in the course of the quench could be used as catalyst for the dehydration of aldoxime. Surprisingly, the reactions gave $>80 \%$ assay yield under these conditions (Table S1, entry 3 and 4 ).

\section{Exploring effect of amount of DMF and water on reaction:}

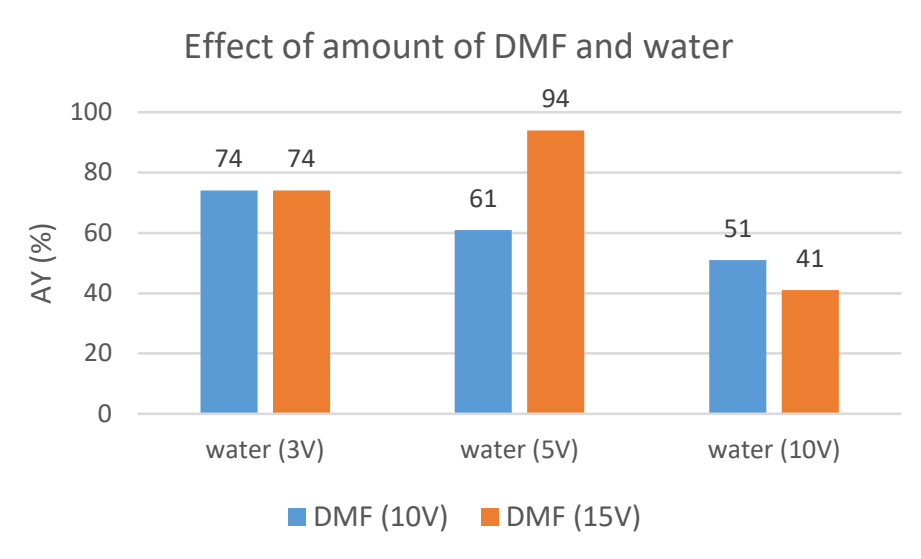

The effect of amount of solvents like, DMF and water on reaction was examined (Table S1, entry 5-10). The reaction with $15 \mathrm{~V}$ of DMF and $5 \mathrm{~V}$ of water provided $94 \%$ assay yield. Importantly, the results were reproduced at $25 \mathrm{~g}$ batch under similar reaction conditions (Table S1, entry 9). The reaction gave $72 \%$ isolated yield (adjusted with 72\% purity). However, the extraction of product was found difficult due to emulsion formation and was not feasible at large scale. This led us to further optimize our reaction conditions to make product isolation easy.

Table S2: Optimization for synthesis of 2-cyanopyrrole from pyrrole under basic conditions.

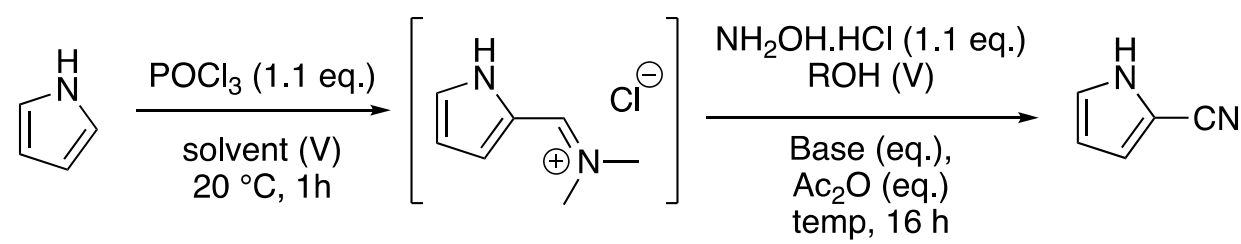

\begin{tabular}{|c|c|c|c|c|c|c|c|c|}
\hline Entry & $\begin{array}{c}\text { Scale } \\
(\mathrm{g})\end{array}$ & Solvent (V) & $\mathrm{ROH}(\mathrm{V})$ & Base (eq.) & $\begin{array}{c}\mathrm{Ac}_{2} \mathrm{O} \\
(\mathrm{eq} .)\end{array}$ & $\begin{array}{c}\mathrm{Temp} . \\
\left({ }^{\circ} \mathrm{C}\right)\end{array}$ & $\begin{array}{c}\mathrm{AY} \\
(\%)\end{array}$ & $\begin{array}{c}\text { IY } \\
(\text { Purity) } \\
(\%)\end{array}$ \\
\hline 1 & 0.2 & $\mathrm{DMF}(10)$ & $\mathrm{H}_{2} \mathrm{O}(3)$ & Pyridine (5) & 1.2 & 90 & 92 & - \\
\hline 2 & 0.2 & $\mathrm{DMF}(10)$ & $\mathrm{EtOH}(3)$ & Pyridine (5) & 1.2 & 90 & 93 & - \\
\hline 3 & 0.2 & $\mathrm{MeCN}(10)$ & $\mathrm{EtOH}(3)$ & Pyridine (5) & 1.2 & 90 & 88 & - \\
\hline 4 & 0.2 & $\mathrm{MeCN}(10)$ & $\mathrm{EtOH}(3)$ & Pyridine (3.5) & 1.2 & 90 & 88 & - \\
\hline 5 & 25 & $\mathrm{MeCN}(10)$ & $\mathrm{EtOH}(3)$ & Pyridine (3.5) & 1.1 & 70 & - & $81(58)$ \\
\hline 6 & 5 & $\mathrm{MeCN}(10)$ & $\mathrm{H}_{2} \mathrm{O}(3)$ & Pyridine (3.5) & 1.2 & 70 & - & $93(80)$ \\
\hline 7 & 25 & $\mathrm{MeCN}(10)$ & $\mathrm{H}_{2} \mathrm{O}(3)$ & Pyridine (3.5) & 1.1 & 70 & - & $76(90)$ \\
\hline
\end{tabular}




\begin{tabular}{|c|c|c|c|c|c|c|c|c|}
\hline 8 & 5 & DMF (10) & $\mathrm{H}_{2} \mathrm{O}(3.5)$ & $\begin{array}{c}\text { Pyridine (10 } \\
\text { mol\%) + 50\% } \\
\mathrm{NaOH}(3.5 \text { eq.) }\end{array}$ & 1.2 & 90 & - & 59 \\
\hline 9 & 50 & DMF (5) & $\mathrm{H}_{2} \mathrm{O}(3)$ & $\begin{array}{c}\text { Pyridine (10 } \\
\text { mol\%) }+50 \% \\
\text { NaHCO } \\
\text { eq.) }\end{array}$ & 1.1 & 90 & - & $64(63)$ \\
\hline 10 & 25 & DMF (10) & $\mathrm{H}_{2} \mathrm{O}(3)$ & Pyridine (5) & 1.1 & 90 & - & $90(89)$ \\
\hline 11 & 100 & DMF (10) & $\mathrm{H}_{2} \mathrm{O}(3)$ & Pyridine (5) & 1.1 & 90 & - & $94(85)$ \\
\hline
\end{tabular}

Next, the reactions were attempted under basic conditions by activating the in situ formed oxime with acetic anhydride. Initially, the reactions were performed with pyridine (5 eq.) and acetic anhydride (1.2 equiv.) in DMF (Table 2S, entry 1 and 2). The reactions were smooth and provided excellent assay yields $(>90 \%)$.

Reaction screening for alternative solvents and amount of ethanol required for reaction:

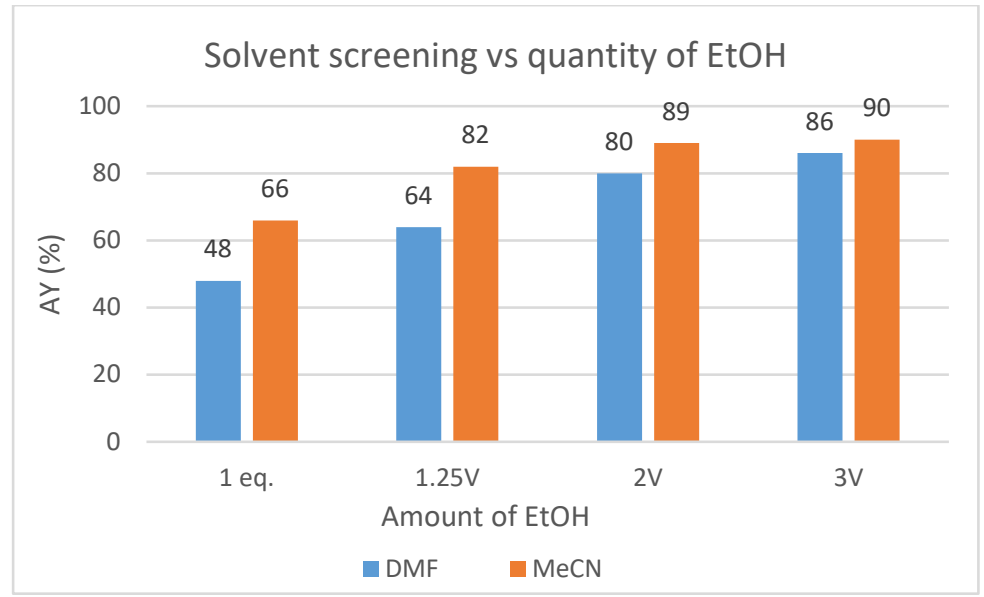

Exploring solvent volumes and amount of pyridine:

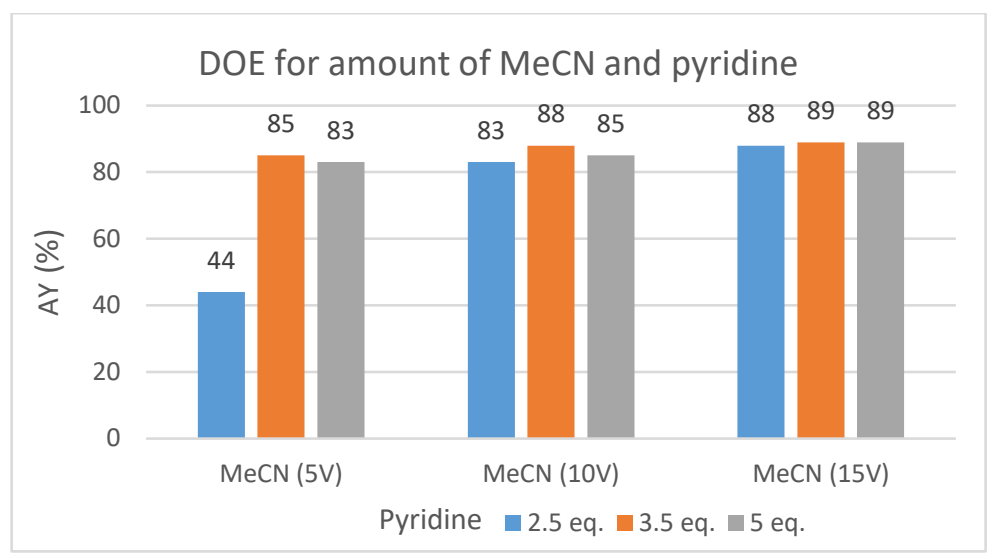


Further, the reaction was screened for an alternative solvents, concentration and reagents. In this regard, few experiments were performed on $0.2 \mathrm{~g}$ scale, and it was found that DMF and acetonitrile works well. Acetonitrile would be better compared to DMF, as it could be easily evaporated from reaction which will be helpful for isolation of the product. With this results in hand, the reaction was scaled up to $25 \mathrm{~g}$ under similar reaction conditions (Table S2, entry 5). The reaction gave $81 \%$ yield with 58\% purity, however, triethylphosphate generated by reaction of $\mathrm{EtOH}$ with residual $\mathrm{POCl}_{3}$ and its associated species was problematic for purification process. The addition of water instead of ethanol resolved this problem and reaction provided excellent yield and purity at $5 \mathrm{~g}$ and $25 \mathrm{~g}$ scale (Table S2, entry 6 and 7). In addition, inorganic bases, $\mathrm{NaHCO}_{3}$ and $\mathrm{NaOH}$, were tried instead of pyridine giving lower yields (Table S2, entry 8 and 9). We ended up with pyridine as best base for the reaction. Importantly, the reaction reproducibility was demonstrated at $100 \mathrm{~g}$ scale (Table S2, entry 11). The product was purified by vacuum distillation and used for next step.

\section{HPLC Trace of Distilled 2-Cyanopyrrole:}

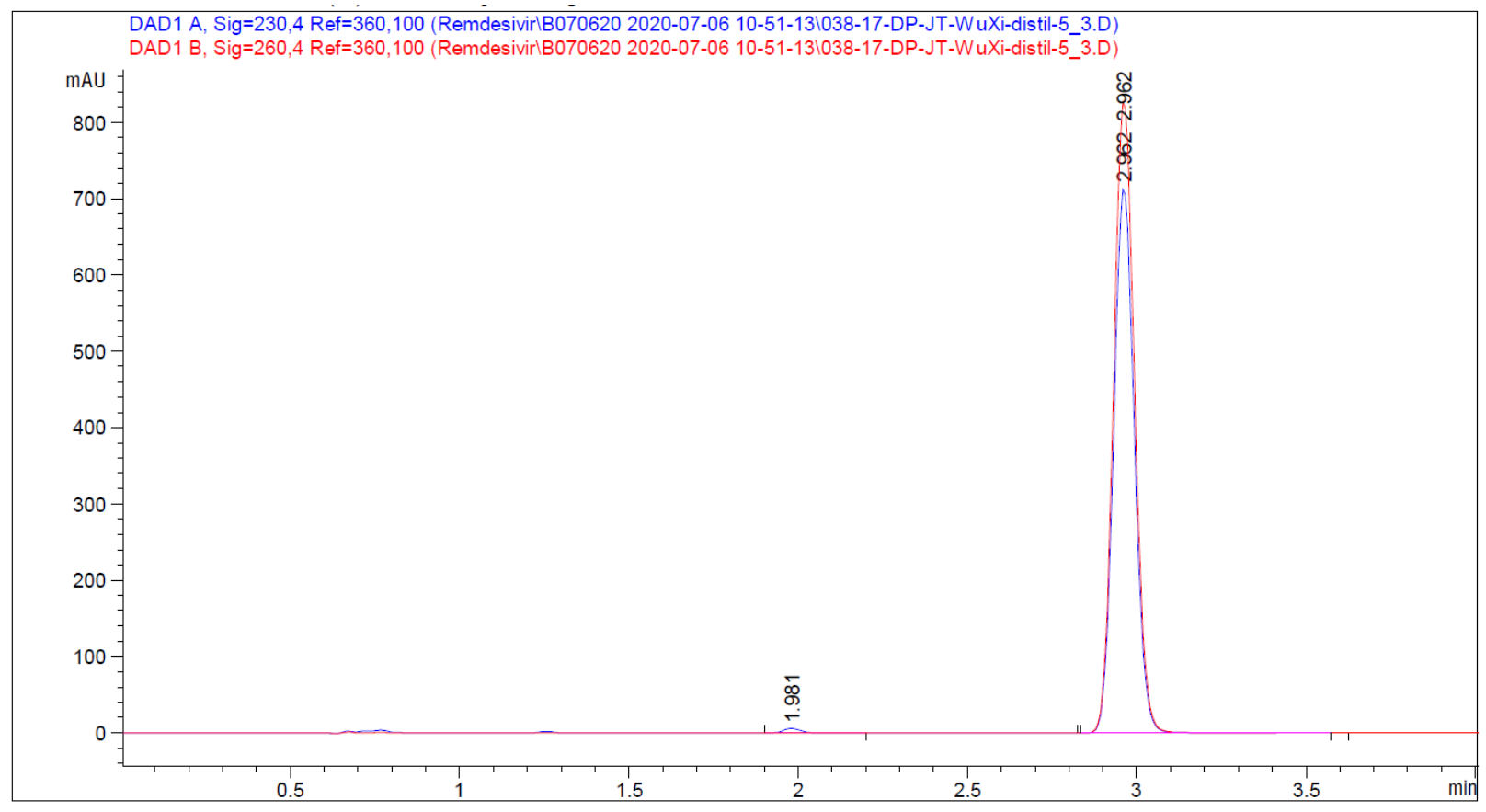




\section{$\underline{N \text {-Amination of 2-Cyanopyrole Using Solid Aminating Reagents }}$}

Table S3: Optimization of $N$-amination of 2-cyanopyrrole with solid aminating reagents $\mathbf{A}$ and $\mathbf{B}$.
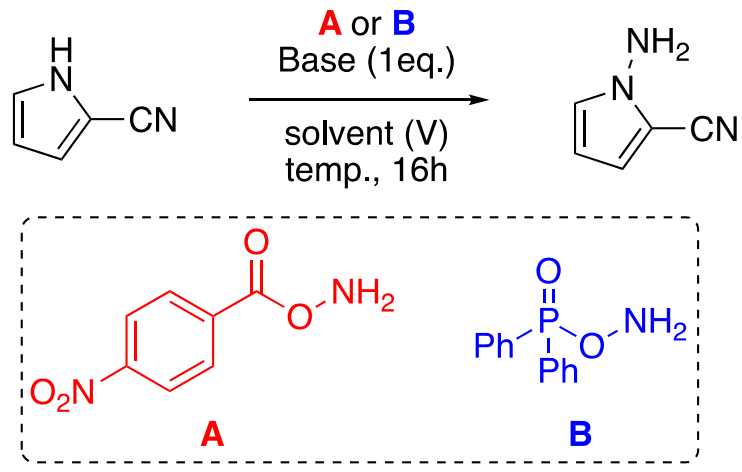

\begin{tabular}{|c|c|c|c|c|c|c|c|c|}
\hline Entry & $\begin{array}{c}\text { Scale } \\
(\mathrm{g})\end{array}$ & $\begin{array}{c}\text { Reagent } \\
(\mathrm{eq.})\end{array}$ & Solvent (V) & Base (eq.) & $\begin{array}{c}\text { Temp } \\
\left({ }^{\circ} \mathrm{C}\right)\end{array}$ & $\begin{array}{c}\text { Conversion } \\
(\text { HPLC area \%) }\end{array}$ & $\begin{array}{c}\text { AY } \\
(\%)\end{array}$ & $\begin{array}{c}\text { Type of } \\
\text { Stirrer }\end{array}$ \\
\hline 1 & 0.1 & $\mathrm{~A}(1.5)$ & $\mathrm{DMF}(150)$ & $\mathrm{NaH}(1.5)$ & 80 & 91 & 89 & Magnetic \\
\hline 2 & 0.1 & $\mathrm{~B}(1.5)$ & $\mathrm{DMF}(200)$ & $\mathrm{NaH}(1.5)$ & 80 & 92 & 94 & Magnetic \\
\hline 3 & 0.5 & $\mathrm{~A}(1.5)$ & $\mathrm{DMF}(25)$ & $\mathrm{NaH}(1.5)$ & 80 & 89 & - & Overhead \\
\hline 4 & 0.5 & $\mathrm{~B}(1.5)$ & $\mathrm{DMF}(40)$ & $\mathrm{NaH}(1.5)$ & 80 & 90 & - & Overhead \\
\hline 5 & 0.1 & $\mathrm{~A}(1.2)$ & $\mathrm{NMP}(100)$ & $\mathrm{KO}^{t} \mathrm{Bu}(1.2)$ & 100 & 94 & 96 & Magnetic \\
\hline 6 & 0.1 & $\mathrm{~B}(1.2)$ & $\mathrm{NMP}(100)$ & $\mathrm{KO}^{t} \mathrm{Bu}(1.2)$ & 100 & 94 & 97 & Magnetic \\
\hline 7 & 0.5 & $\mathrm{~A}(1.2)$ & $\mathrm{NMP}(25)$ & $\mathrm{KO}^{t} \mathrm{Bu}(1.2)$ & 80 & 86 & 87 & Overhead \\
\hline 8 & 0.5 & $\mathrm{~B}(1.2)$ & $\mathrm{NMP}(25)$ & $\mathrm{KO}^{t} \mathrm{Bu}(1.2)$ & 80 & 86 & 86 & Overhead \\
\hline 9 & 1.0 & $\mathrm{~A}(1.1)$ & $\mathrm{NMP}(10)$ & $\mathrm{KO}^{t} \mathrm{Bu}(1.1)$ & 80 & 67 & - & Overhead \\
\hline 10 & 1.0 & $\mathrm{~B}(1.1)$ & $\mathrm{NMP}(15)$ & $\mathrm{KO}{ }^{t} \mathrm{Bu}(1.1)$ & 80 & 95 & 95 & Overhead \\
\hline
\end{tabular}

As discussed in manuscript, in order to avoid dilute reaction conditions and increase throughput for $N$ amination of 2-cyanopyrrole, the solid aminating reagents like, $O$-(4-nitrobenzoyl)hydroxylamine (A) and $O$-(diphenylphosphinyl)hydroxylamine (B) were planned to use. At the outset, in $10 \mathrm{~mL}$ glass vials, the solution of 2-cyanopyrrole (100 mg) in DMF (2 mL) was treated with aminating reagents (A and $\mathbf{B}$; 1.5 eq.; individually) in presence of $\mathrm{NaH}$ (1.5 eq.). However, both reactions were very thick (almost dry) and unable to stir with magnetic stir bar. Then, the reactions were attempted with excess amount of DMF (Table S3, entry 1 and 2 ) and heated at $80{ }^{\circ} \mathrm{C}$ overnight (16 h). The reactions showed $>90 \%$ conversion (by HPLC method). The assay yields were derived by using ${ }^{1} \mathrm{H}$ NMR (mesitylene was used as internal standard). The assay yields showed well agreement with conversion. However, the reactions were highly diluted at this stage. Then, reactions were examined in EasyMax instrument with overhead stirrer employing lower amount of solvents. The reactions were carried out on $500 \mathrm{mg}$ scale with both aminating reagents (A and 
B) in DMF (25V and 40V) under similar reaction conditions (Table 3S, entry 3 and 4). The results were excellent, showing $\sim 90 \%$ conversion in both reactions.

Exploring different solvents and bases with $O$-(4-nitrobenzoyl)hydroxylamine (A) reagent:

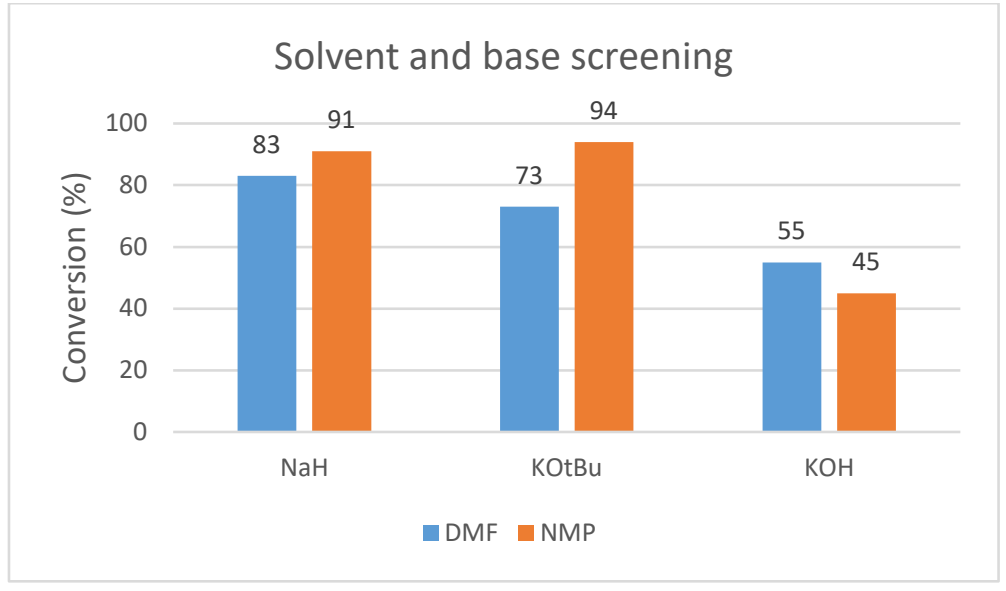

Exploring different solvents and bases with $O$-(diphenylphosphinyl)hydroxylamine (B) reagent:

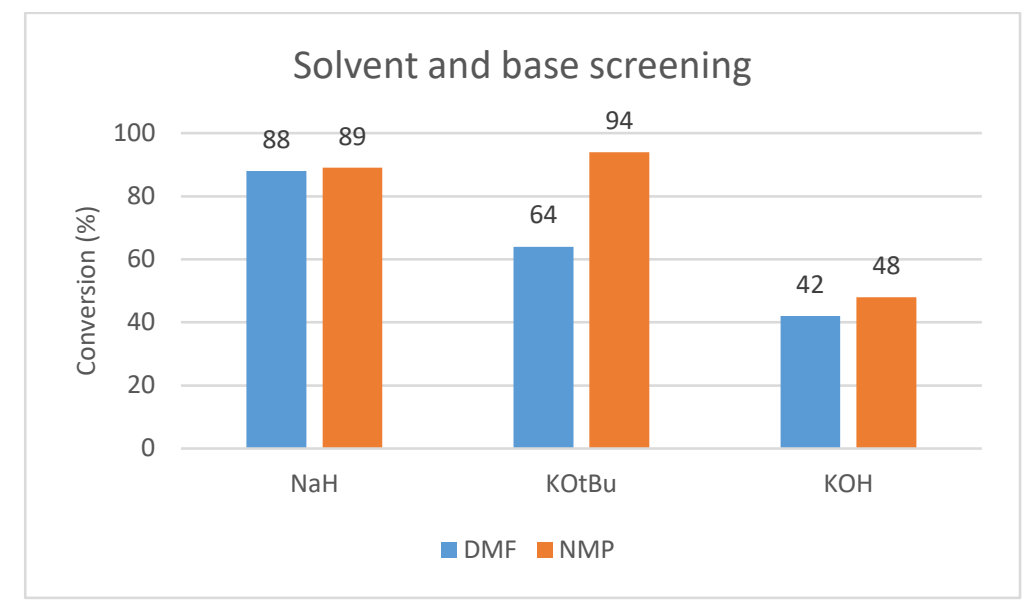

Next, we screened the effect of solvents (DMF and NMP) and bases (NaH, $\mathrm{KO}^{t} \mathrm{Bu}$ and $\mathrm{KOH}$ ) with both aminating reagents ( $\mathbf{A}$ and $\mathbf{B}$ ). NMP and $\mathrm{KO}^{t} \mathrm{Bu}$ combination gave the best result. Both reagents showed 94\% conversion and assay yields were in good agreement with conversion (Table 3S, entry 5 and 6). Further, these reactions conditions were taken up forward for large scale reaction. The reactions were examined to investigate the lowest solvent volume that could be used on EasyMax (Table 3S, entry 7-10). The reactions were carried out on $1.0 \mathrm{~g}$ scale with lowest $10 \mathrm{~V}$ and $15 \mathrm{~V}$ of solvent. The reaction with $15 \mathrm{~V}$ of solvent gave good conversion and assay yield.

Procedure for synthesis of $\mathrm{N}$-amination of 2-cyanopyrrole:

A $50 \mathrm{~mL}$ glass reactor was equipped in EasyMax instrument with an internal temperature probe, overhead stirrer and nitrogen line. The flask was charged with anhydrous NMP $(15 \mathrm{~mL})$ and cooled to an internal temperature of $0-5{ }^{\circ} \mathrm{C}$ under an atmosphere of nitrogen. With stirring (300 RPM), 2-cyanopyrrole (1.0 g. $10.86 \mathrm{mmol}, 1.0$ eq.) was charged. Then, solid $\mathrm{KO}^{t} \mathrm{Bu}$ (1.34 g, $11.94 \mathrm{mmol}, 1.1$ eq.) was added to reaction mixture. The temperature was raised to $10{ }^{\circ} \mathrm{C}$, reactions stirred for 10 minutes. To the reaction mixture 
solid $O$-(diphenylphosphinyl)hydroxylamine (2.78 g, $11.94 \mathrm{mmol}, 1.1$ eq.) was charged in four portions over 10 minutes. The temperature of reaction was slowly increased to $80{ }^{\circ} \mathrm{C}$ and then reaction continued for overnight (16 hours). The consumption of the starting 2-cyanopyrrole was monitored with HPLC (95\%) and assay yield (95\%) was derived by using ${ }^{1} \mathrm{H}$ NMR. 


\section{$\underline{\text { Investigation of } \mathrm{NH}_{2}} \underline{\mathrm{Cl} \text { Extraction }}$}

$3.00 \mathrm{~g}$ of $\mathrm{NH}_{4} \mathrm{Cl}(57.2 \mathrm{mmol})$ was added to a $250 \mathrm{~mL}$ Erlenmeyer flask along with $4.70 \mathrm{~mL}$ of $14.5 \mathrm{M}$ $\mathrm{NH}_{4} \mathrm{OH}(68.1 \mathrm{mmol})$. The mixture was cooled to $-5^{\circ} \mathrm{C}$ and stirred on a magnetic hotplate. $72 \mathrm{~mL}$ of bleach (2.2 M, $158 \mathrm{mmol}$ ) was added via addition funnel over the course of 15 minutes. The concentration of the bleach was stated as $7.5 \% \mathrm{NaOCl}$ (7.1\% active chlorine) which translates to $15.8 \mathrm{wt} \% \mathrm{NaOCl}$ and $2.2 \mathrm{M}$ $\mathrm{NaOCl}$ as found by iodometric titration. Some of this apparent difference in concentration exists as a result of ambiguity in tradeterms of the bleaching industry. The same procedure was used with more concentrated bleach, but the portions of reagent were changed as follows: $4.08 \mathrm{~g} \mathrm{NH}_{4} \mathrm{Cl}, 6.39 \mathrm{~mL} \mathrm{NH}_{4} \mathrm{OH}$, and $72 \mathrm{~mL}$ of $10.6 \% \mathrm{NaOCl}$ were mixed. Care should be taken working with monochloramine. It is a reactive oxidant.

The mixture reacted for 10 minutes at $-5{ }^{\circ} \mathrm{C}$ prior to sampling. The aqueous feed was then held at this temperature through course of the study. $8 \mathrm{~mL}$ aliquots were taken to explore extraction of $\mathrm{NH}_{2} \mathrm{Cl}$ into organic solvent under various conditions. The aqueous chloramine was added to a $20 \mathrm{~mL}$ scintillation vial and vigorously shaken with organic solvent for 30 seconds. The biphasic mixture was allowed to separate and $1 \mathrm{~mL}$ of the organic phase was removed and titrated by the iodometric titration (See below). The results are listed in the table below.

Iodometric Titration: $6.20 \mathrm{~g}$ of $\mathrm{Na}_{2} \mathrm{~S}_{2} \mathrm{O}_{3} \cdot 5\left(\mathrm{H}_{2} \mathrm{O}\right)$ was dissolved in $250 \mathrm{~mL}$ of water and set aside. $0.5 \mathrm{~g}$ of starch was dissolved in $50 \mathrm{~mL}$ of water by heating (hot plate) to $80{ }^{\circ} \mathrm{C}$ for 10 minutes and then set aside. $0.8 \mathrm{~g}$ of $\mathrm{NaI}$ was dissolved in $200 \mathrm{~mL}$ of water, and $10 \mathrm{~mL}$ of $\mathrm{AcOH}$ and $10 \mathrm{~mL}$ of the starch indicator were added. $20 \mathrm{~mL}$ of the iodide solution was transferred to a $50 \mathrm{~mL}$ Erlenmeyer flask with stir bar. $1.00 \mathrm{~mL}$ of $\mathrm{NH}_{2} \mathrm{Cl}$ in organic solvent was added to the iodide solution which turned a purplish brown color. The oxidant solution was stirred rapidly on a magnetic hotplate. The thiosulphate solution was added dropwise until the solution became clear. The volume required to quench the oxidant was recorded and molarity of $\mathrm{NH}_{2} \mathrm{Cl}$ was recorded.

Perhaps the difference between the reported and observed values can be explained as follows. A significant amount of volatile $\mathrm{NH}_{2} \mathrm{Cl}$ could be lost as the literature procedure evaporates the organic layer prior to filtration. ${ }^{3}$ Also, the concentration of $\mathrm{NaOCl}$ was not stated. Strength of commercial bleach varies widely.

pH of reagents and reaction mixture (for batch conditions):

1) $\mathrm{NH}_{4} \mathrm{Cl}(3.00 \mathrm{~g})+\mathrm{NH}_{4} \mathrm{OH}(4.7 \mathrm{~mL}): 13.0\left(\mathrm{NH}_{4} \mathrm{Cl}\right.$ was not fully soluble)

2) Clorox (7.5\% of $\mathrm{NaOCl}): 13.4$

3) $\mathrm{NH}_{4} \mathrm{Cl}(3.00 \mathrm{~g})+\mathrm{NH}_{4} \mathrm{OH}(4.7 \mathrm{~mL})+$ Clorox $(7.5 \%$ of NaOCl, $72 \mathrm{~mL}): 13.5$

4) $\mathrm{NH}_{2} \mathrm{Cl}$ (extracted in MTBE): 11.5

5) Aqueous layer (after extraction of $\mathrm{NH}_{2} \mathrm{Cl}$ ): 14.0

$\mathrm{pH}$ of reagents and reaction mixture (for CSTR conditions):

1) $\mathrm{NH}_{4} \mathrm{Cl}$ (3.00 g in $5 \mathrm{~mL}$ water): 6.0

2) $\mathrm{NH}_{4} \mathrm{Cl}(3.00 \mathrm{~g}$ in $5 \mathrm{~mL}$ water $)+\mathrm{NH}_{4} \mathrm{OH}(4.7 \mathrm{~mL}): 12.0$

3) $\mathrm{NH}_{4} \mathrm{Cl}(3.00 \mathrm{~g}$ in $5 \mathrm{~mL}$ water $)+\mathrm{NH}_{4} \mathrm{OH}(4.7 \mathrm{~mL})+$ Clorox (7.5\% of $\left.\mathrm{NaOCl}, 72 \mathrm{~mL}\right): 14.0$

4) $\mathrm{NH}_{2} \mathrm{Cl}$ (extracted in MTBE): 12.5

5) Aqueous layer (after extraction of $\mathrm{NH}_{2} \mathrm{Cl}$ ): 14.0

Note: $\mathrm{pH}$ measured with a $\mathrm{pH}$ meter 
Table S4: Chloramine concentration from different solvents and bleach sources

\begin{tabular}{|c|c|c|c|}
\hline Entry & Solvent (Volume) & NaOCl (\%) & $\mathrm{NH}_{2} \mathrm{Cl}(\mathrm{M})$ \\
\hline 1 & Reported Literature Value & unknown & 0.09 \\
\hline 2 & MTBE (11 mL)—(Repeat of Literature Procedure) & $7.5(2.2 \mathrm{M})$ & 0.53 \\
\hline 3 & MTBE (5.5 mL, 50\% MTBE Charge) & ” & 0.66 \\
\hline 4 & MTBE (3.7 mL, 25\% MTBE Charge) & ” & 0.89 \\
\hline 5 & MTBE (11 mL) & $10.6(2.99 \mathrm{M})$ & 0.65 \\
\hline 6 & MTBE (5.5 mL) & “ & 0.83 \\
\hline 7 & MTBE (5.5 mL)—organic saturated with NaOAc & “ & 0.81 \\
\hline 8 & $\begin{array}{l}\text { MTBE (5.5 mL)—aqueous layer saturated with } \\
\qquad \mathrm{NaCl}\end{array}$ & “ & 0.84 \\
\hline 9 & MTBE (3.7 mL) & ” & 0.90 \\
\hline 10 & $\mathrm{Et}_{2} \mathrm{O}(3.7 \mathrm{~mL})$ & ” & 0.79 \\
\hline 11 & 2-Methyl THF (3.7 mL) & ” & 0.80 \\
\hline 12 & Dioxane (6 mL) & ” & 0.86 \\
\hline 13 & CPME & “ & 0.98 \\
\hline 14 & DEGDBE (3.7 mL) & ” & 1.05 \\
\hline 15 & THF (3.7 mL) & ” & 1.19 \\
\hline
\end{tabular}




\section{Continuous Production of Chloramine}

A continuous stirred tank reactor (CSTR) was constructed from a $100 \mathrm{~mL}$ Schlenk flask with a liquid fill level set at $100 \mathrm{~mL}$. Bleach, $\mathrm{NH}_{4} \mathrm{Cl} / \mathrm{NH}_{4} \mathrm{OH}$, and MTBE feeds were positioned below the liquid level surface, and the dip tubes removing reaction fluids were placed at the top of the fluid surface level, the 100 $\mathrm{mL}$ fill level volume. The CSTR was equipped with a large oval shaped stir bar, stirred at $800 \mathrm{rpm}$, and cooled to $-5{ }^{\circ} \mathrm{C}$. The total flow rate of fluids entering the CSTR was set at $10 \mathrm{~mL} / \mathrm{min}$ to give a residence time of $10 \mathrm{~min}$. The exit flow was set at $12 \mathrm{~mL} / \mathrm{min}$, faster than the entering flow to ensure a reactor volume of $100 \mathrm{~mL} / \mathrm{min}$. The exit stream flowed into the bottom of a gravity liquid-liquid settler made from a simple pressure-equalizing addition funnel $(25 \mathrm{~mL})$. The funnel was filled to a level of $25 \mathrm{~mL}$, allowing the organic and aqueous layers to separate, and then the aqueous layer (bottom) was drained from the addition funnel, while the MTBE layer containing $\mathrm{NH}_{2} \mathrm{Cl}$ was pumped off the top layer. Steady state was reached 30 minutes after the start of pumping ( $0.45 \mathrm{M} \mathrm{NH}_{2} \mathrm{Cl}$ in MTBE).

The input feeds for the CSTR are as follows. $75.0 \mathrm{~g}$ of $\mathrm{NH}_{4} \mathrm{Cl}(1.43 \mathrm{~mol}), 117.5 \mathrm{~mL}$ of concentrated $\mathrm{NH}_{4} \mathrm{OH}$ and $125 \mathrm{~mL}$ of $\mathrm{H}_{2} \mathrm{O}$ were combined and stirred until the mixture was homogeneous (Stream A). The total volume was $300 \mathrm{~mL}$, and pumped at a rate of $0.619 \mathrm{~mL} / \mathrm{min}$ (Stream A). Aqueous $\mathrm{NaOCl}$ was pumped at a rate of $3.71 \mathrm{~mL} / \mathrm{min}$ (Stream B). Some ambiguity exists in the terminology describing concentration of $\mathrm{NaOCl}$. Our bleach was 7.5\% $\mathrm{NaOCl}$ (7.1\% active chlorine, $15.8 \mathrm{wt} \% \mathrm{NaOCl}, 2.2 \mathrm{M} \mathrm{NaOCl}$ as found by iodometric titration). MTBE was pumped at a rate of $5.67 \mathrm{~mL} / \mathrm{min}$ (Stream C). The exit dip tubes were programmed to remove solution at a rate of $12 \mathrm{~mL} / \mathrm{min}$ (2 pumps flowing at 5 and $7 \mathrm{~mL} / \mathrm{min}$ ). Peristaltic pumps from Vapourtec were used for fluid transport.

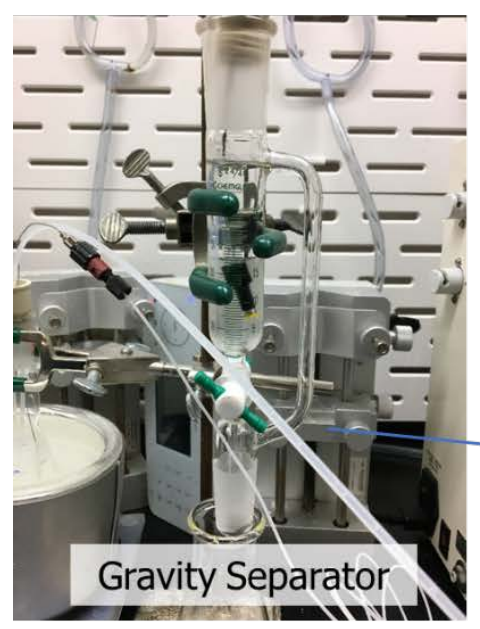

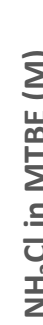

\section{6} 0.5

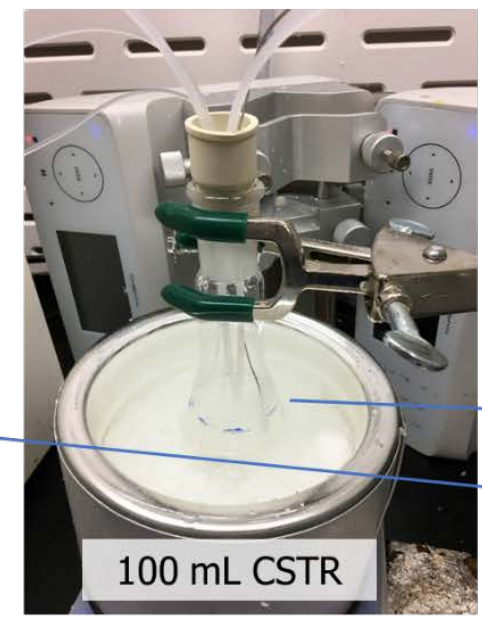

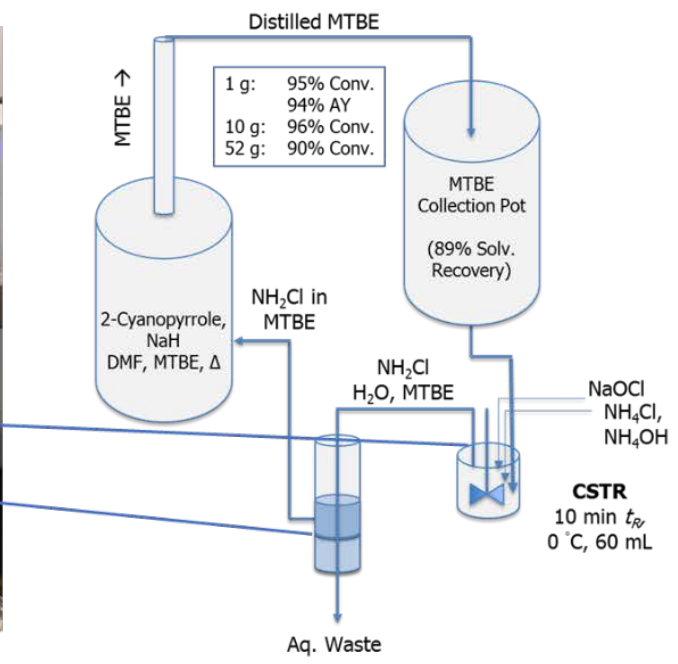

Titration of $\mathrm{NH}_{2} \mathrm{Cl}$ from CSTR
.5
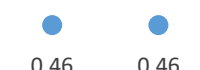

0.44

0.44

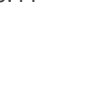

25

35

$$
\text { Time ( } \mathrm{min})
$$

\section{5}




\section{Batch Amination with $\mathrm{NH}_{2} \mathrm{Cl}$ from CSTR}

2-Cyanopyrrole ( $9.21 \mathrm{~g}, 10.0 \mathrm{mmol}$ ) was added to a $500 \mathrm{~mL}$ 3-neck round-bottom flask along with $100 \mathrm{~mL}$ of DMF. The solution was cooled to $0{ }^{\circ} \mathrm{C}$ with an ice-bath. $5.00 \mathrm{~g}$ of $60 \mathrm{wt} \% \mathrm{NaH}$ in mineral oil was added slowly with stirring, keeping temperature below $35^{\circ} \mathrm{C}$. The round-bottom was connected to two condensers connected in series and cooled to $-20^{\circ} \mathrm{C}$ with a chiller. The condensers were configured to drain into a 250 $\mathrm{mL}$ receiving flask which was used to recycle the MTBE.

After the CSTR reached steady state, the stream of $\mathrm{NH}_{2} \mathrm{Cl}$ in MTBE was connected to the basified pot of 2-cyanopyrrole. The $\mathrm{NH}_{2} \mathrm{Cl}$ was added at a rate of $5.67 \mathrm{~mL} / \mathrm{min}$. It was added in 5 portions, where each fraction was flowed into the cyanopyrrole for 15 minutes. After every 15 minute addition, the chloramine feed was removed from the amination pot. The reaction vessel was set to $30{ }^{\circ} \mathrm{C}$ and placed under vacuum. The MTBE distilled and was collected in the receiving flask. After 14 minutes of evaporation, vacuum was turned off and the vessel was returned to atmospheric pressure. The MTBE was recycled and returned to the feedline used to extract $\mathrm{NH}_{2} \mathrm{Cl}$ in the CSTR (Stream C).

After the fifth addition of chloramine, conversion was measured as 93\%, and $360 \mathrm{~mL}$ of MTBE was recovered (84\% recovery). 


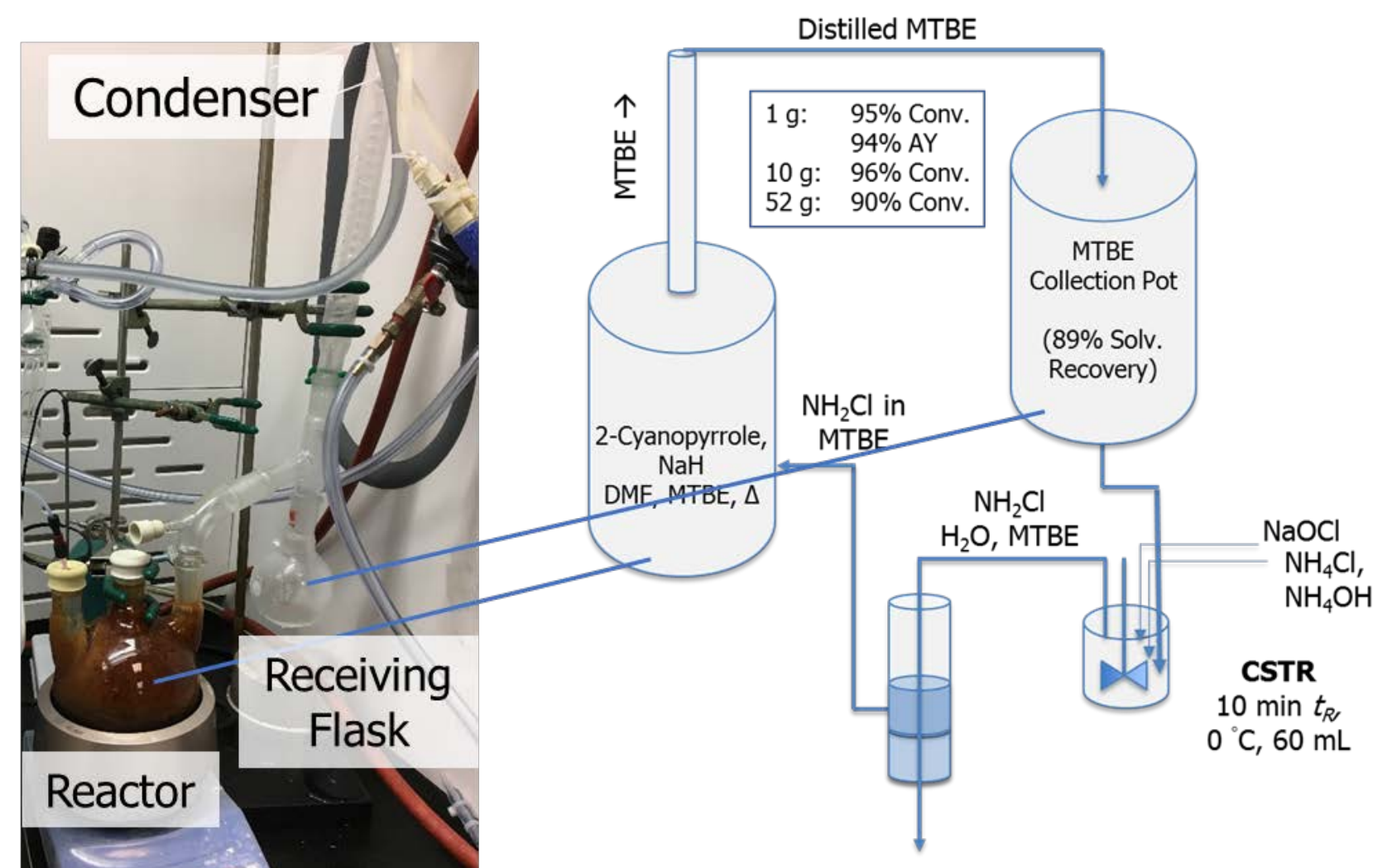

Aq. Waste

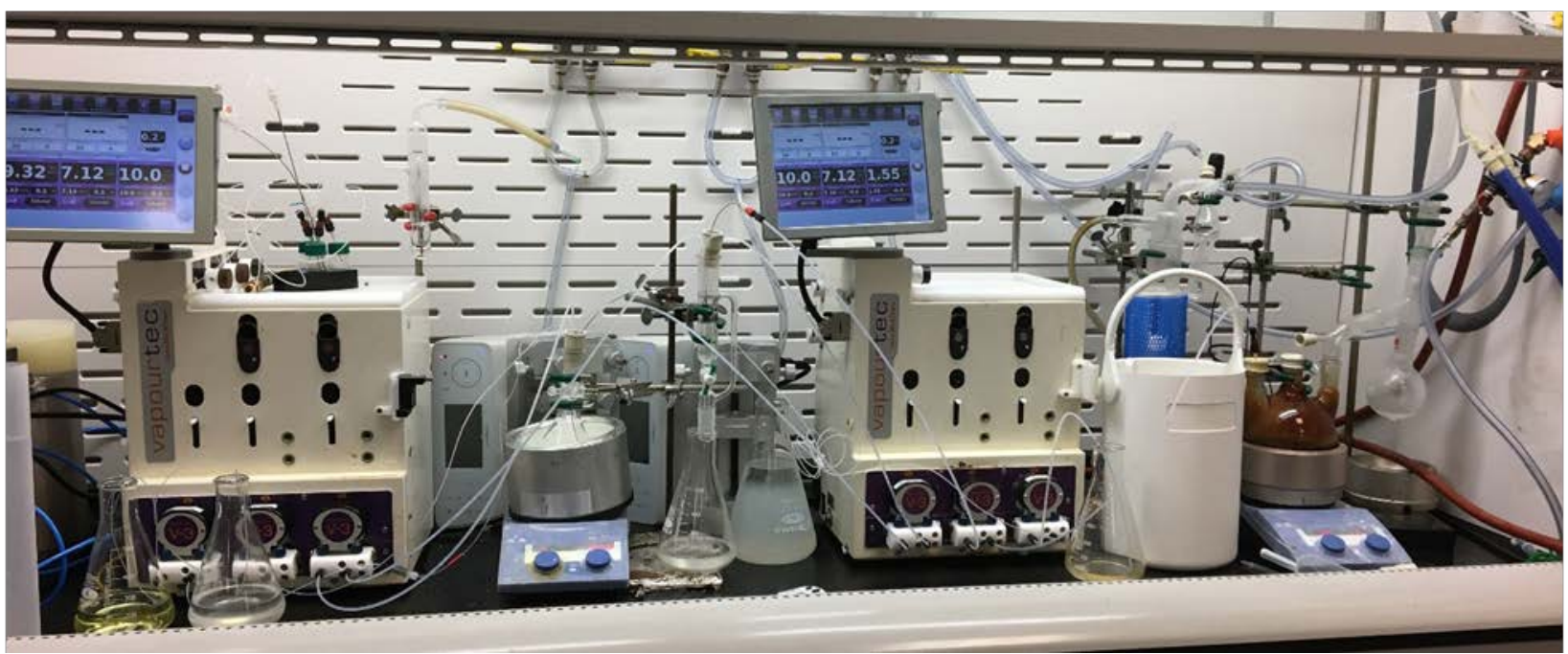




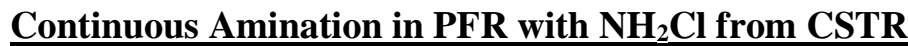

A CSTR was made as described above in a $22 \mathrm{~mL}$ Scintillation vial with a fill volume of $20 \mathrm{~mL}$. The total flow rate in was $2 \mathrm{~mL} / \mathrm{min}$, the exit was programmed at $3 \mathrm{~mL} / \mathrm{min}$, and the residence time was $10 \mathrm{~min}$.

The input feeds for the CSTR are as follows. $15.0 \mathrm{~g}$ of $\mathrm{NH}_{4} \mathrm{Cl}(286 \mathrm{~mol}), 23.5 \mathrm{~mL}$ of concentrated $\mathrm{NH}_{4} \mathrm{OH}$ and $25 \mathrm{~mL}$ of $\mathrm{H}_{2} \mathrm{O}$ were combined and stirred until the mixture was homogeneous (Stream A). The total volume was $60 \mathrm{~mL}$, and pumped at a rate of $0.124 \mathrm{~mL} / \mathrm{min}$ by syringe pump (Stream A). Aqueous $\mathrm{NaOCl}$ was pumped at a rate of $0.742 \mathrm{~mL} / \mathrm{min}$ (Stream B). MTBE was pumped at a rate of $1.13 \mathrm{~mL} / \mathrm{min}$ (Stream C). The exit dip tube was programmed to remove solution at a rate of $3 \mathrm{~mL} / \mathrm{min}$, and it transported the biphasic mixture to the gravity separator as described previously. Peristaltic pumps from Vapourtec were used for fluid transport.

The $\mathrm{NH}_{2} \mathrm{Cl}$ in MTBE was pumped at a rate of 1.13 from the gravity separator, and mixed with a solution of 2-cyanopyrrole anion (0.609 M in DMF) via a T-Mixer (Idexx, 0.02 “ ID). The 2-cyanopyrrole mixture was flowed at $0.129 \mathrm{~mL} / \mathrm{min}$ by syringe pump. The solution was made by dissolving $1.40 \mathrm{~g}$ of 2cyanopyrrole (15.2 mmol, 1.00 equiv.), $1.22 \mathrm{~g} \mathrm{NaH}$ (60 wt\%, $30.4 \mathrm{mmol}, 2.00$ equiv.) in DMF to reach a total volume of $25 \mathrm{~mL}$. The reaction mixture flowed into a PFR constructed from PFA tubing (0.06” ID, $5.04 \mathrm{~mL}, 4 \mathrm{~min} t_{\mathrm{R}}$ ). The reaction ran for 12 minutes before collecting sample for analysis. $89 \%$ conversion was observed. 


\section{Batch Amination with Multicharge of Chloramine}

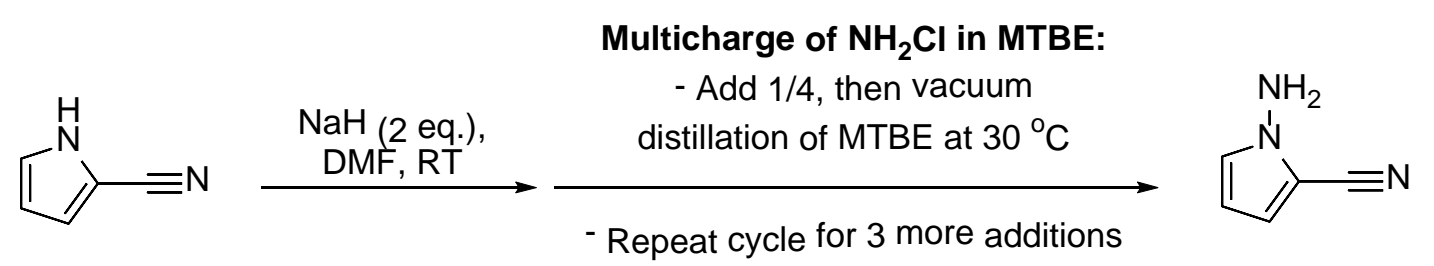

Typical multi-charge amination procedure:

To a solution of $1 H$-pyrrole-2-carbonitrile $(0.46 \mathrm{~g}, 5 \mathrm{mmol})$ in MTBE $(5 \mathrm{~mL})$ was added NaH (0.40 g, 10.0 mmol, $60 \%$ in mineral oil) in portions, and the reaction was stirred for $20 \mathrm{~min}$ at room temperature. DMF ( $5 \mathrm{~mL}$ ) was added and MTBE was distilled under vacuum at $20-30{ }^{\circ} \mathrm{C} . \mathrm{NH}_{2} \mathrm{Cl}$ in $\mathrm{MTBE}(5 \mathrm{~mL}, 0.59 \mathrm{M}$ solution) was added via syringe. The mixture was let to stir between $20-30^{\circ} \mathrm{C}$ for 5 min and HPLC analysis was carried out. MTBE was distilled under vacuum at $20-30{ }^{\circ} \mathrm{C}$ and $\mathrm{NH}_{2} \mathrm{Cl}$ in $\mathrm{MTBE}(5 \mathrm{~mL}, 0.59 \mathrm{M}$ solution) was added via syringe. MTBE was distilled under vacuum at $20-30{ }^{\circ} \mathrm{C}$ and this cycle was repeated 2 more times. Mesitylene was added as internal standard and the reaction was assayed by quantitative ${ }^{1} \mathrm{H}$ NMR. This procedure was consistently repeated in 1, 5 and $30 \mathrm{mmol}$ scale (Table S5).

Table S5. Conversion and assay yield of chloramine multicharge reactions

\begin{tabular}{|c|c|c|c|}
\hline \multirow{2}{*}{ Chloramine charge } & \multicolumn{3}{|c|}{ Conversion (HPLC area \%) } \\
\cline { 2 - 4 } & $\begin{array}{c}\mathbf{1} \text { mmol } \\
(\mathbf{0 . 0 9 2} \mathbf{~ g})\end{array}$ & $\begin{array}{c}\mathbf{5} \mathbf{~ m m o l} \\
\mathbf{( 0 . 4 6 0} \mathbf{~ g})\end{array}$ & $\begin{array}{c}\mathbf{3 0} \mathbf{~ m m o l} \\
\mathbf{( 2 . 8} \mathbf{~ g})\end{array}$ \\
\hline 1 & 43 & 38 & 43 \\
\hline 2 & 70 & 72 & 70 \\
\hline 3 & 86 & 92 & 89 \\
\hline 4 & 98 & 98 & 98 \\
\hline $\begin{array}{c}\text { Assay Yield } \\
\text { (NMR) }\end{array}$ & $\mathbf{8 7 \%}$ & $\mathbf{9 1 \%}$ & $\mathbf{8 9 \%}$ \\
\hline
\end{tabular}




\section{Monochloramine (0.59M in MTBE) preparation procedure:}

$\mathrm{NH}_{4} \mathrm{Cl}$ (3.0 g) in MTBE (55 mL) was cooled to $-5^{\circ} \mathrm{C}$ (internal temperature), and concentrated $\mathrm{NH}_{4} \mathrm{OH}$ (4.7 $\mathrm{mL}$ ) was added. Commercial bleach $(72 \mathrm{~mL}$, Clorox $\sim 7.5 \% \mathrm{NaOCl})$ was then added via addition funnel over $15 \mathrm{~min}$. The mixture was stirred for $15 \mathrm{~min}$, the layers were separated, and the organic layer was washed with brine $(1 \times 30 \mathrm{~mL})$. The organic layer was dried over powdered $\mathrm{CaCl}_{2}$ in the freezer for at least $1 \mathrm{~h}$ and kept at the same temperature. Approximate concentration is $0.59 \mathrm{M}$. 


\section{Amination and Triazine Formation in One-Pot}

For scale-up to $10 \mathrm{~g}$, a few changes were implemented: 1) In order to increase the throughput of the overall process, DMF was reduced from $10 \mathrm{~V}$ to $5 \mathrm{~V}$ in relation to $1 \mathrm{H}$-pyrrole-2-carbonitrile with no impact to the reaction profile; 2) Based on our findings on the relation of $\mathrm{NaH} v s$ chloramine (see manuscript for details), $\mathrm{NaH}$ was reduced from 2 to 1.5 equiv.; 3) The number of chloramine charges were reduced from 4 to 3. This procedure was employed at in $2.8 \mathrm{~g}$ and $10 \mathrm{~g}$ scale furnishing the $N$-amino-2-cyanopyrrole product in $92 \%$ assay yield (Table S6, entries 1 and 2). The $N$-amino-2-cyanopyrrole product was cyclized by adding 3 equiv. of formamidine acetate and heating at 90-95 ${ }^{\circ} \mathrm{C}$ for $16 \mathrm{~h}$. Assay ${ }^{1} \mathrm{H}$ NMR using $1,3,5-$ trimethoxybenzene as internal standard showed $76 \%$ assay yield to triazine, which was isolated in $64 \%$ isolated yield after reducing the DMF volume and addition of water (78\% purity). Preliminary purification studies showed that $>97 \%$ pure triazine can be obtained by recrystallizing the crude solid from boiling water/EtOH (1:1), however, further studies showed that trituration with MTBE was more efficient for mass recovery in good purity.

Aiming at further increasing the throughput, more concentrated solutions of chloramine were investigated. Instead of using Clorox ( 7.5\% $\mathrm{NaOCl}$ ), a sodium hypochlorite $10-15 \%$ solution from Sigma-Aldrich was used to prepare a ca. $0.74 \mathrm{M}$ chloramine solution in MTBE. By the addition of $170 \mathrm{~mL}$ ( $\sim 1.2$ equiv.) of this solution to deprotonated $1 \mathrm{H}$-pyrrole-2-carbonitrile (10.0 g scale) in DMF gave $98 \%$ conversion to the $\mathrm{N}$ amino-2-cyanopyrrole product (Table S6, Entry 4). It is important to mention that this batch employed a total of 22 volumes of solvent ( $5 \mathrm{~V}$ of DMF $+17 \mathrm{~V}$ of chloramine solution in MTBE), a reduction of approximately 5-fold compared to the Hynes Jr. procedure ${ }^{4}$ (20V of DMF $+80 \mathrm{~V}$ of chloramine solution). The $\mathrm{N}$-amino-2-cyanopyrrole solution was subjected to cyclization with formamidine acetate. The crude solid obtained from this batch was further purified by trituration with MTBE to give triazine in $60 \%$ isolated yield over the two steps.
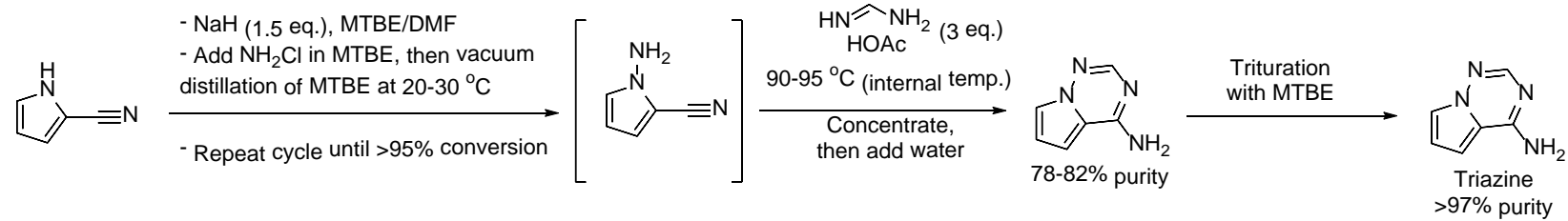

Table S6: Scale-up to $10 \mathrm{~g}$ and evaluation of concentrated chloramine solution

\begin{tabular}{|c|c|c|c|c|c|c|c|}
\hline Entry & $\begin{array}{l}\text { Scale } \\
\text { (g) }\end{array}$ & $\begin{array}{l}\text { Chloramine in } \\
\text { MTBE charge } \\
\text { (concentration) }\end{array}$ & $\begin{array}{l}\text { Amination } \\
\text { conversio } \\
\mathrm{n} \text { (HPLC) }\end{array}$ & $\begin{array}{l}\text { Cyclizatio } \\
\text { n AY }\left({ }^{1} \mathrm{H}\right. \\
\text { NMR })\end{array}$ & $\begin{array}{l}\text { Purity } \\
\text { (HPL } \\
\text { C) }\end{array}$ & $\begin{array}{c}\text { IY } \\
\text { yield }\end{array}$ & Comments \\
\hline 1 & 2.8 & $\begin{array}{c}3 \text { charges } \\
(3 \times 40 \mathrm{~mL}) \\
\text { Conc.: } 0.56 \mathrm{M}\end{array}$ & $97 \%$ & $74 \%$ & $82 \%$ & $62 \%$ & \\
\hline 2 & 10.0 & $\begin{array}{c}3 \text { charges } \\
(3 \times 140 \mathrm{~mL}) \\
\text { Conc.: } 0.56 \mathrm{M}\end{array}$ & $\begin{array}{c}98 \% \\
(92 \% \text { AY) }\end{array}$ & $76 \%$ & $78 \%$ & $64 \%$ & $\begin{array}{c}\text { Analysis of the mother liquor } \\
\text { showed } \sim 2 \text { g of triazine ( } 14 \% \\
\text { yield) }\end{array}$ \\
\hline 3 & 10.0 & $\begin{array}{c}2 \text { charges } \\
(220+50 \mathrm{~mL}) \\
\text { Conc.: } 0.68 \mathrm{M} \\
\end{array}$ & $99 \%$ & NA & $98 \%$ & $63 \%$ & $\begin{array}{c}\text { Crude solid was } \\
\text { resuspended/triturated in MTBE } \\
\text { to give } 98 \% \text { purity triazine. }\end{array}$ \\
\hline 4 & 10.0 & $\begin{array}{c}1 \text { charge } \\
(170 \mathrm{~mL}) \\
\text { Conc.: } 0.74 \mathrm{M}\end{array}$ & $98 \%$ & $75 \%$ & $99 \%$ & $60 \%$ & $\begin{array}{l}\text { Crude solid was } \\
\text { resuspended/triturated in MTBE } \\
\text { to give } 99 \% \text { purity triazine. }\end{array}$ \\
\hline
\end{tabular}


HPLC trace of commercial Triazine (red) and M4ALL triazine (green):

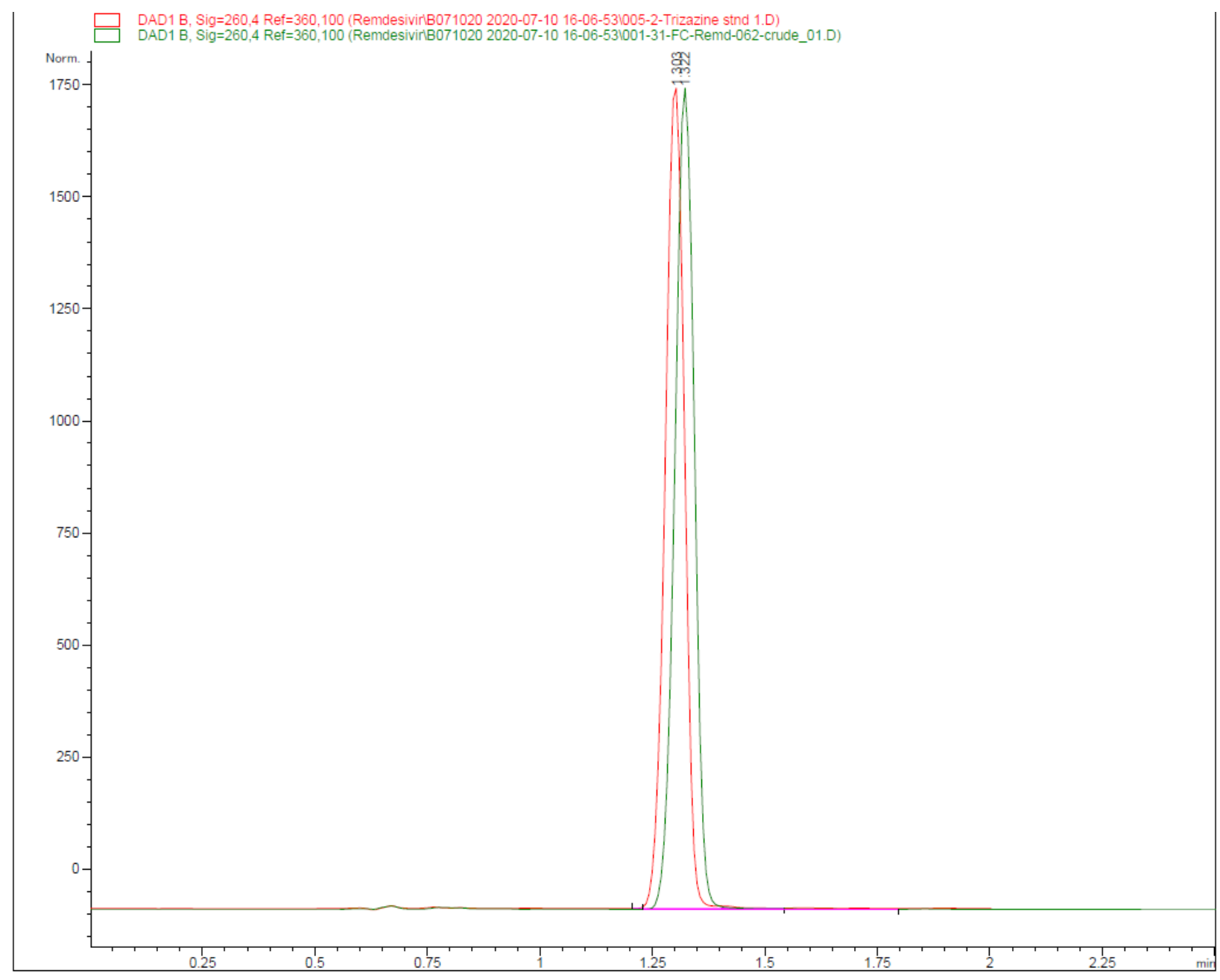


Evaluation of Alternative Bases and Solvents for Addressing Safety in the Amination step

We concluded our amination investigation by addressing the hazards surrounding use of $\mathrm{NaH}$ in conjunction with DMF. An interesting solution is the deprotonation of $1 H$-pyrrole-2-carbonitrile in MTBE, then solvent swap to DMF before adding the chloramine (Table S7, entry 2). This alternative was employed in the $10 \mathrm{~g}$ batches previously discussed. Alternative solvents and bases were also evaluated. Prior experience at M4ALL Institute ${ }^{5}$ suggested that $\mathrm{NaH}$ deprotonation can be successful in "glyme type" solvents. Diglyme and diethylene glycol dibutyl ether (DEDGBE) were explored furnishing high conversion to the desired $N$-aminated product (Table S7, Entries 3 and 4). THF and MTBE were also investigated, however, lower conversion was obtained (Table S7, entries 5 and 6). These results confirm the importance of the coordinating nature of the "glyme type" ethers which can be used as an alternative to DMF. Different bases like, NaHMDS, $\mathrm{NaO}^{t} \mathrm{Bu}$ and $\mathrm{KO}^{t} \mathrm{Bu}$ were examined, however the product is formed in reasonable conversion, the reaction profiles did not excel the use of $\mathrm{NaH}$ as base (Table S7, Entries 7-9).

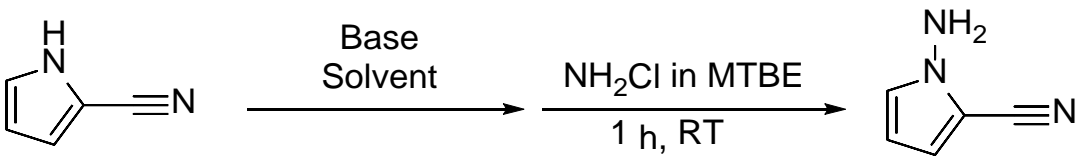

\section{Typical amination screening procedure:}

To a solution of $1 H$-pyrrole-2-carbonitrile $(1 \mathrm{mmol})$ in DMF or alternative solvent $(1 \mathrm{~mL})$ was added $\mathrm{NaH}$ or alternative base, and the reaction was stirred for $30 \mathrm{~min}$ at room temperature. $\mathrm{NH}_{2} \mathrm{Cl}(4 \mathrm{~mL}$, ca. $0.56 \mathrm{M}$ in MTBE) was added via syringe. The reaction conversion was monitored by HPLC after 1 hour.

Table S7: Evaluation of alternative bases and solvents for the amination reaction

\begin{tabular}{|c|c|c|c|c|c|}
\hline Entry & Solvent & Base (equiv.) & $\begin{array}{l}\text { Conversion } \\
\text { (HPLC) }\end{array}$ & $\begin{array}{c}\text { AY } \\
\text { (NMR) }\end{array}$ & Comments \\
\hline 1 & DMF & $\mathrm{NaH}$ (1.1 to 2$)$ & $>95 \%$ & $89-95 \%$ & $\begin{array}{l}\text { See the manuscript for relation } \\
\text { between } \mathrm{NaH} \text { and Chloramine }\end{array}$ \\
\hline 2 & MTBE/DMF & $\mathrm{NaH}(2)$ & $>95 \%$ & - & $\begin{array}{l}\text { Deprotonation was carried out in } \\
\text { MTBE, then DMF was added and } \\
\text { MTBE was distilled before } \\
\text { adding chloramine solution }\end{array}$ \\
\hline 3 & Diglyme & $\mathrm{NaH}(1.5)$ & $>95 \%$ & $97 \%$ & - \\
\hline 4 & $\begin{array}{l}\text { Diethylene } \\
\text { glycol } \\
\text { dibutyl ether } \\
\text { (DEGDBE) }\end{array}$ & $\mathrm{NaH}(2)$ & $>95 \%$ & $92 \%$ & - \\
\hline 5 & MTBE & $\mathrm{NaH}(2)$ & $45 \%$ & - & - \\
\hline 6 & THF & $\mathrm{NaH}(1.5)$ & $26 \%$ & - & - \\
\hline 7 & DMF & $\begin{array}{c}\text { NaHMDS } \\
(1.5)\end{array}$ & $73 \%$ & - & 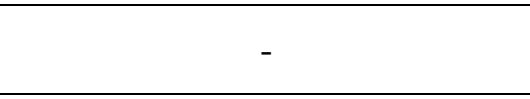 \\
\hline 8 & DMF & $\mathrm{NaO}^{t} \mathrm{Bu}(1.5)$ & $71 \%$ & - & \multirow{2}{*}{$\begin{array}{c}\text { For a full screening of sodium } \\
\text { and potassium tert-butoxide } \\
\text { equivalents, see table S8 }\end{array}$} \\
\hline 9 & $\mathrm{DMF}$ & $\mathrm{KO}^{t} \mathrm{Bu}(1.5)$ & $81 \%$ & - & \\
\hline
\end{tabular}


Table S8: Evaluation of Sodium and Potassium tert-butoxide equivalents for the amination reaction

\begin{tabular}{|c|c|c|c|}
\hline Entry & Equiv. & Base & $\begin{array}{c}\text { Conversion (HPLC } \\
\text { area \%) }\end{array}$ \\
\hline 1 & \multirow{2}{*}{1} & $\mathrm{KO}^{t} \mathrm{Bu}$ & 69 \\
\hline 2 & & $\mathrm{NaO}^{t} \mathrm{Bu}$ & 80 \\
\hline 3 & \multirow{2}{*}{1.2} & $\mathrm{KO}^{t} \mathrm{Bu}$ & 85 \\
\hline 4 & & $\mathrm{NaO}^{t} \mathrm{Bu}$ & 80 \\
\hline 5 & \multirow{2}{*}{1.5} & $\mathrm{KO}^{t} \mathrm{Bu}$ & 81 \\
\hline 6 & & $\mathrm{NaO}^{t} \mathrm{Bu}$ & 71 \\
\hline 7 & \multirow{2}{*}{2} & $\mathrm{KO}^{t} \mathrm{Bu}$ & 78 \\
\hline 8 & & $\mathrm{NaO}^{t} \mathrm{Bu}$ & 66 \\
\hline 9 & \multirow{2}{*}{2.5} & $\mathrm{KO}^{t} \mathrm{Bu}$ & 62 \\
\hline 10 & & $\mathrm{NaO}^{t} \mathrm{Bu}$ & 46 \\
\hline 11 & \multirow{2}{*}{3} & $\mathrm{KO}^{t} \mathrm{Bu}$ & 31 \\
\hline 12 & & $\mathrm{NaO}^{t} \mathrm{Bu}$ & 19 \\
\hline 13 & \multirow{2}{*}{4} & $\mathrm{KO}^{t} \mathrm{Bu}$ & 0 \\
\hline 14 & & $\mathrm{NaO}^{t} \mathrm{Bu}$ & 0 \\
\hline
\end{tabular}


NMR spectra

${ }^{1} \mathrm{H}$ NMR Spectra of Intermediate Iminium Chloride Salt in DMSO- $d_{6}$ at 600 MHz:

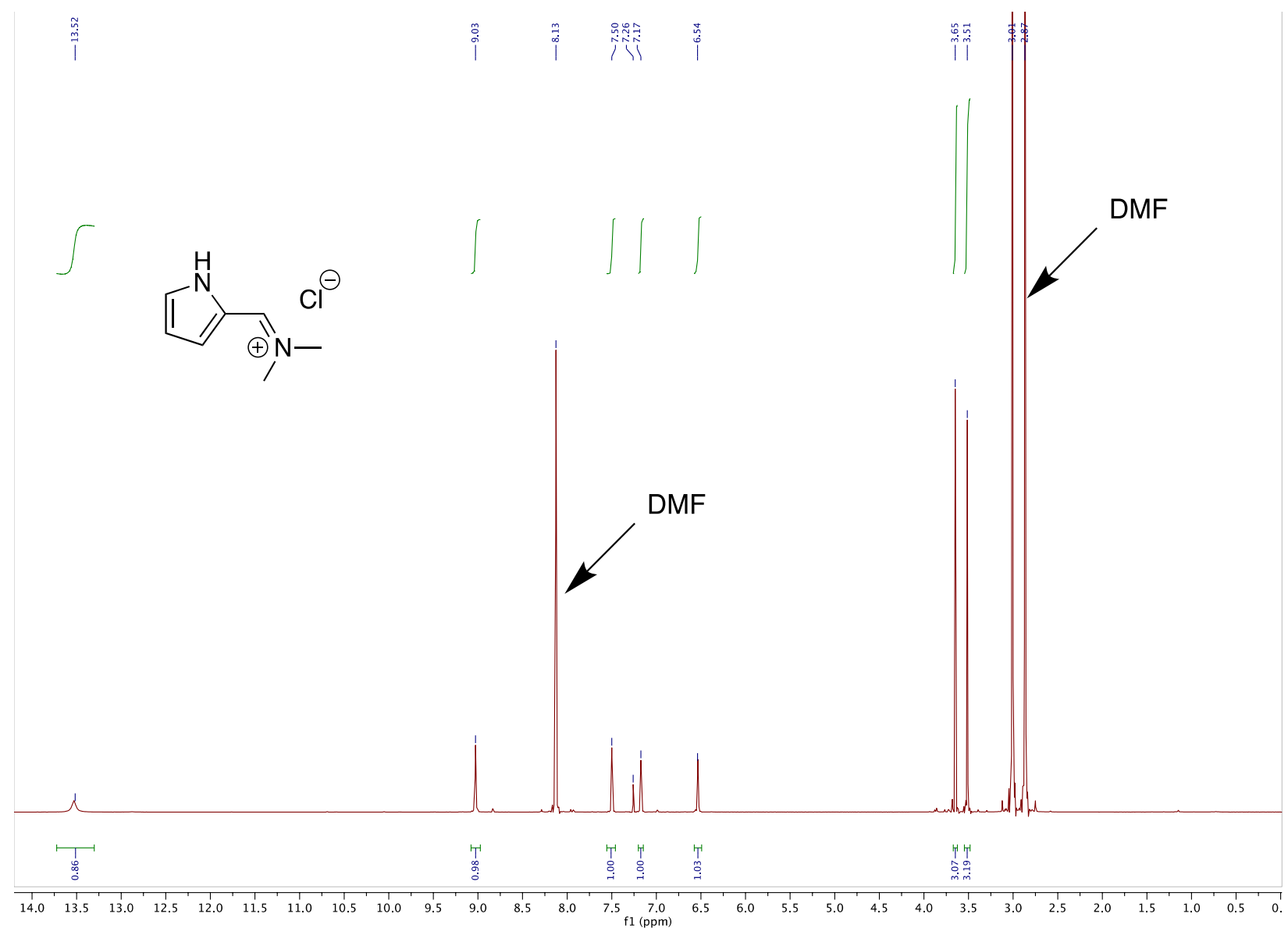


${ }^{1} \mathrm{H}$ NMR Spectra 2-Cyanopyrrole in DMSO-d $d_{6}$ at $600 \mathrm{MHz}$ :

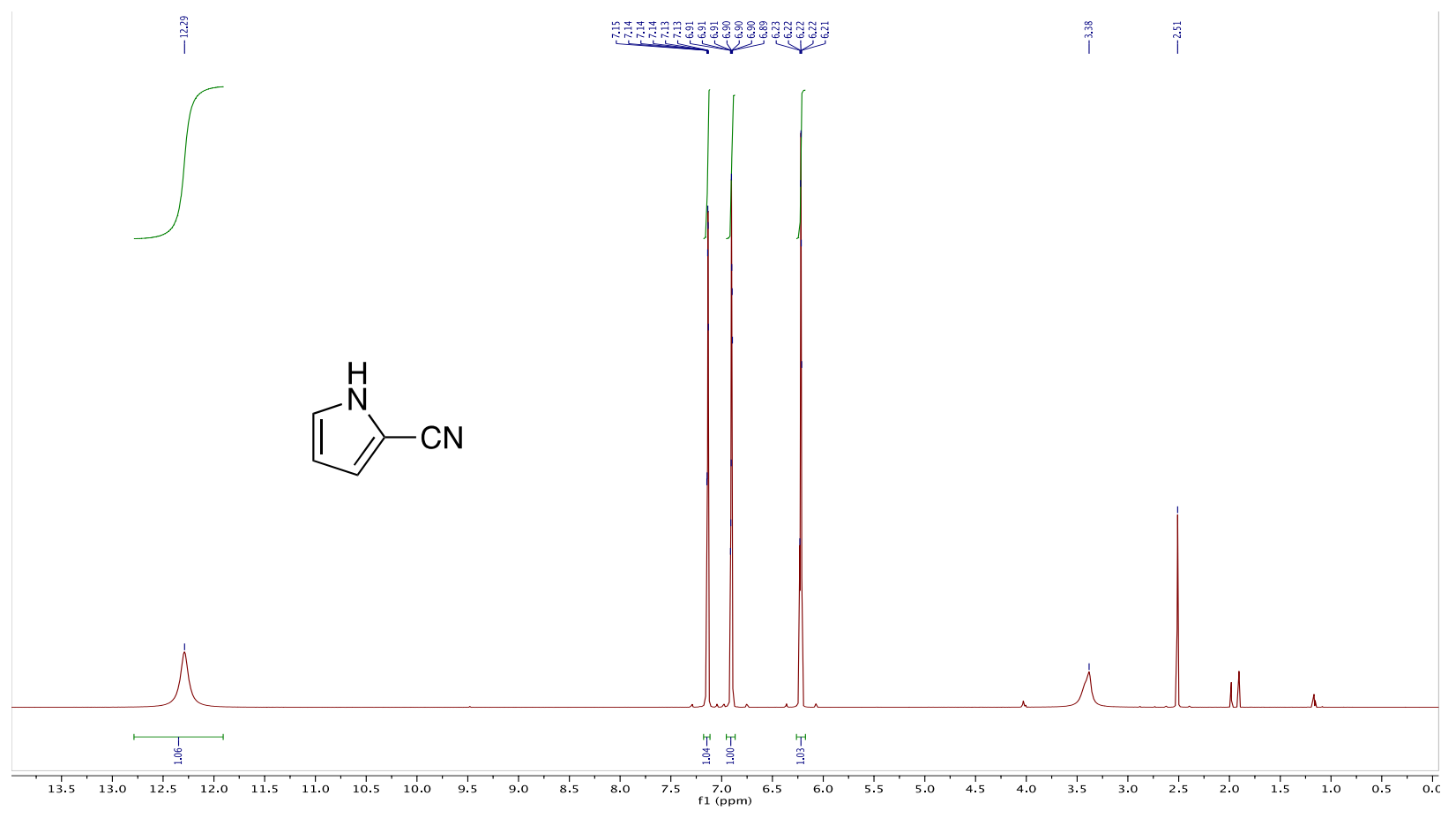

${ }^{13} \mathrm{C}$ NMR Spectra 2-Cyanopyrrole in DMSO-d 6 at $151 \mathrm{MHz:}$

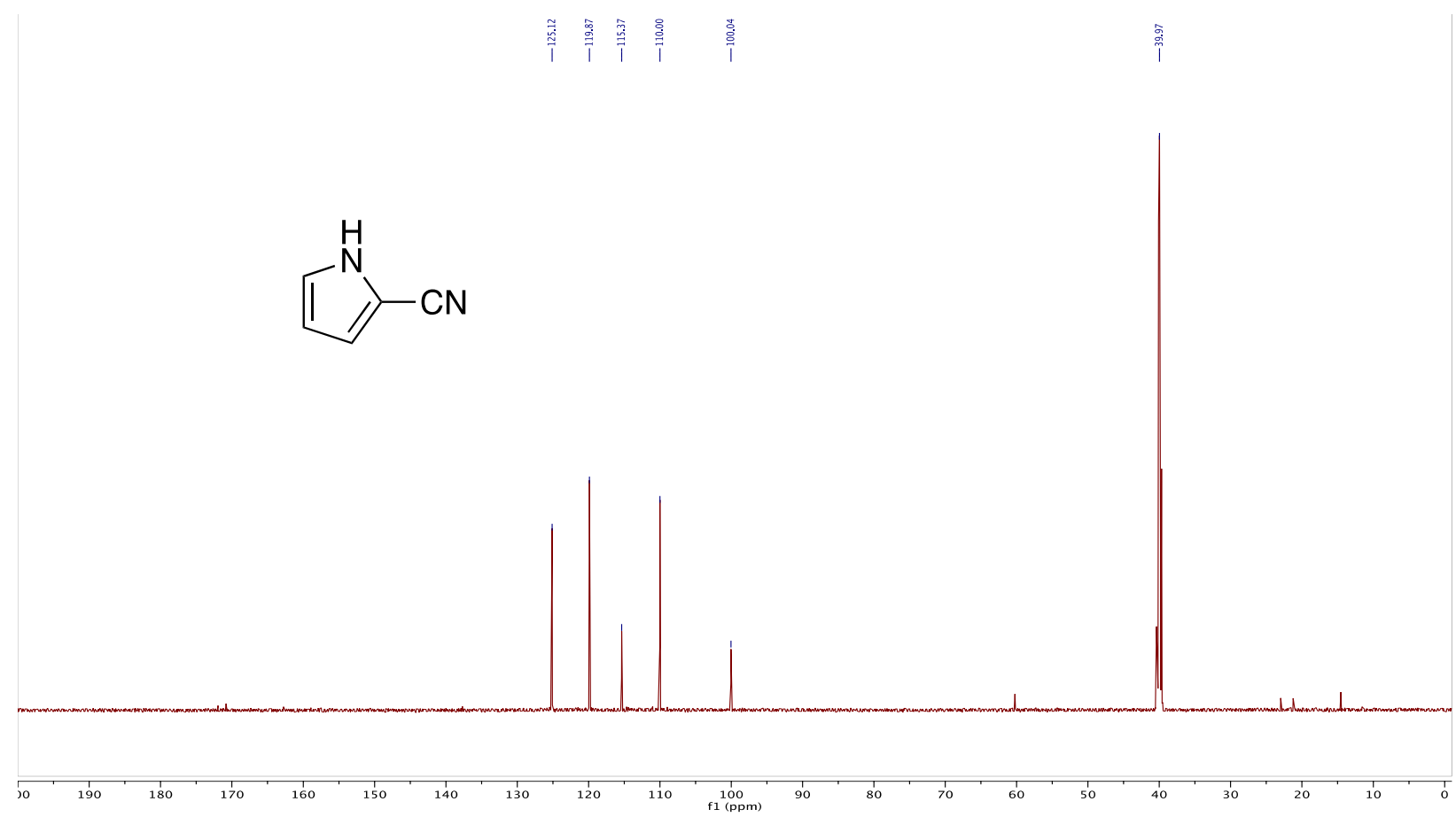


Typical ${ }^{1} \mathrm{H}$ NMR spectrum of reaction mixture after amination step in DMSO-d ${ }_{6}(600 \mathrm{MHz})$ : FC-remd-058-amination 11 "C:Users \cardos of DesktopiNMRiRemdesivir NMR" PROTON DMSO \{C:LrukertTopSpin3.5p17\} MoQuade 18

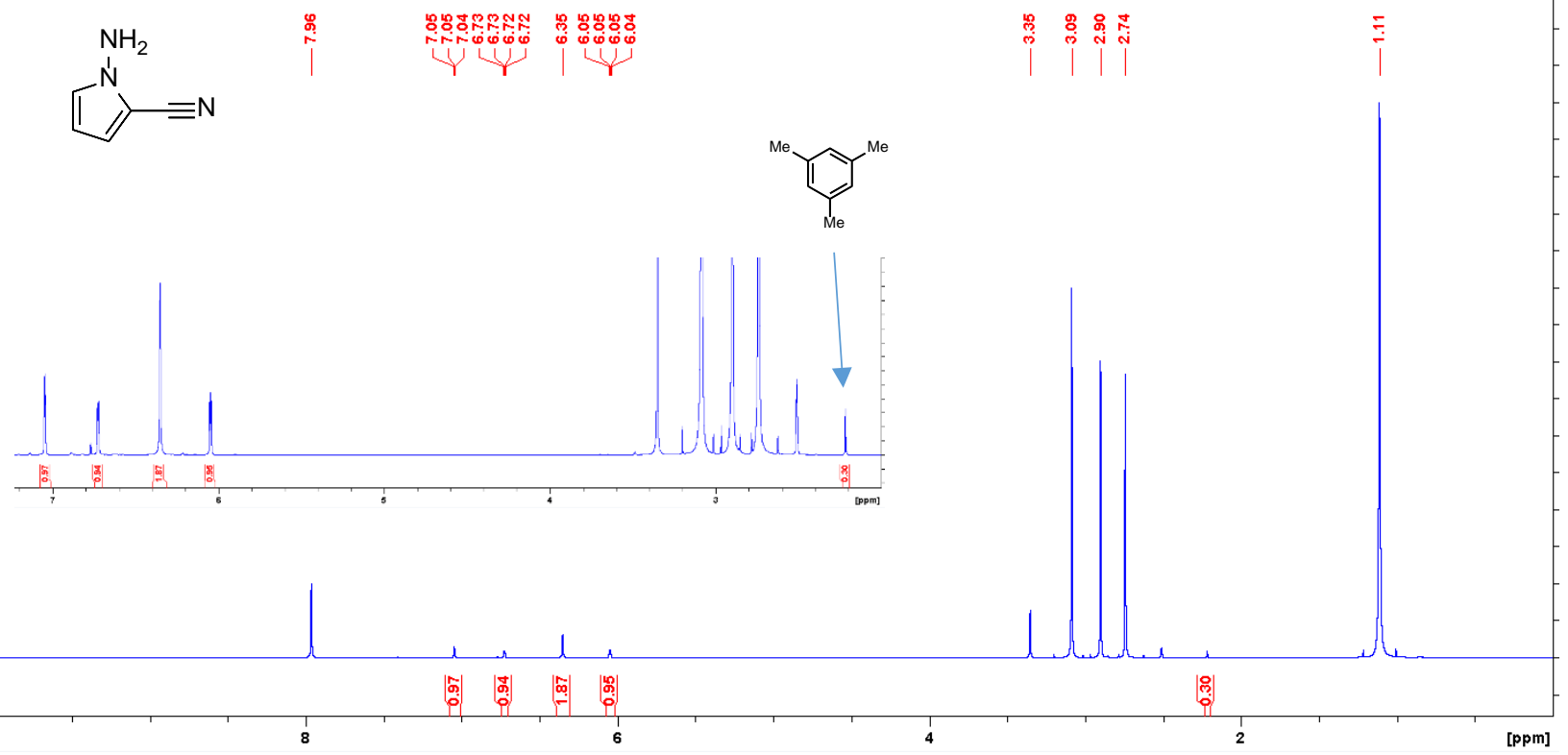

Typical ${ }^{1} \mathrm{H}$ NMR spectrum of crude reaction mixture after cyclization step in DMSO- $\boldsymbol{d}_{6}(600 \mathrm{MHz})$ :

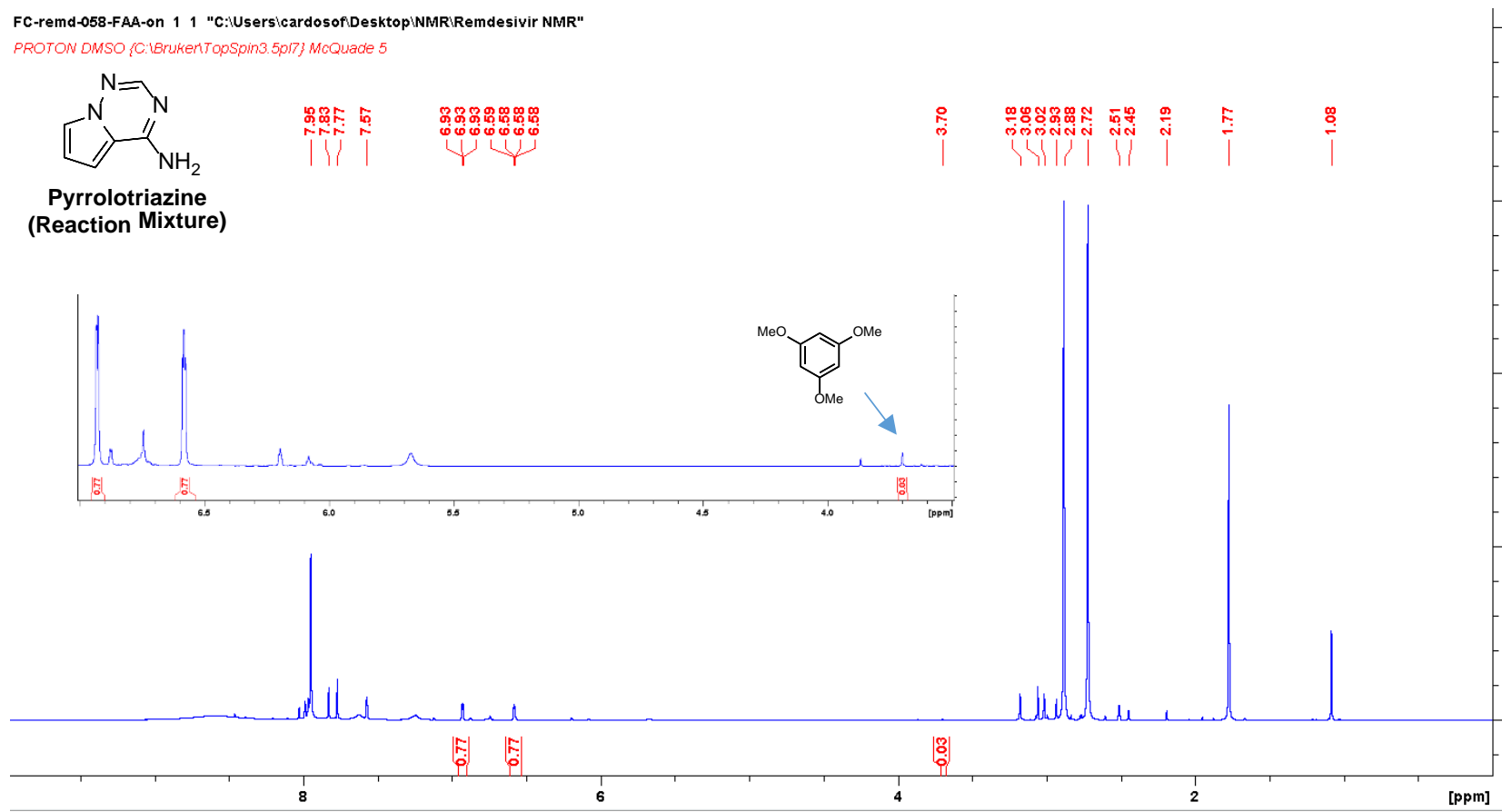


${ }^{1} \mathrm{H}$ NMR spectrum of triazine in DMSO-d ${ }_{6}$ at $600 \mathrm{MHz}$ :

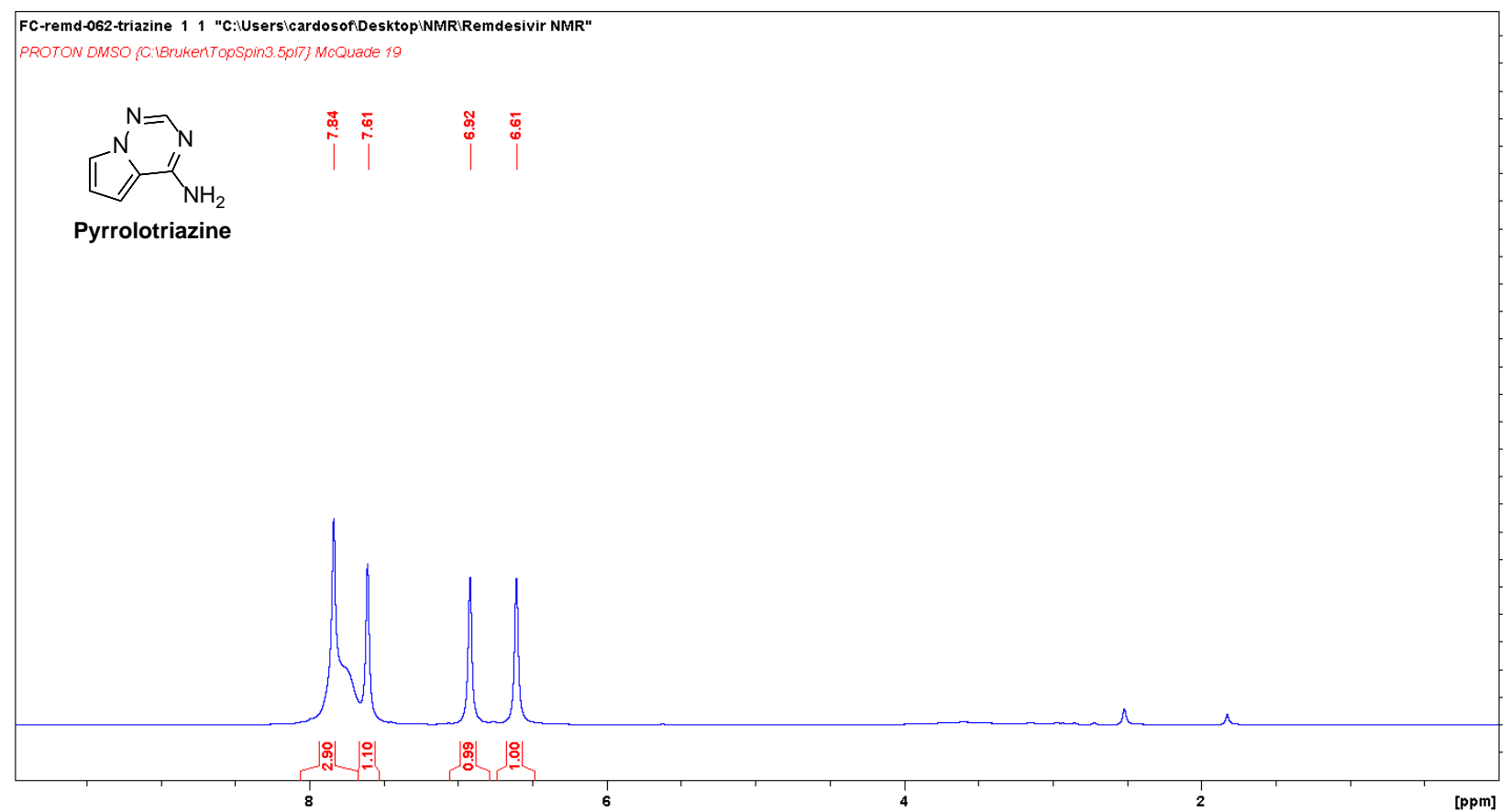

${ }^{13} \mathrm{C}$ NMR spectrum of triazine in DMSO-d $d_{6}$ at $151 \mathrm{MHz:}$

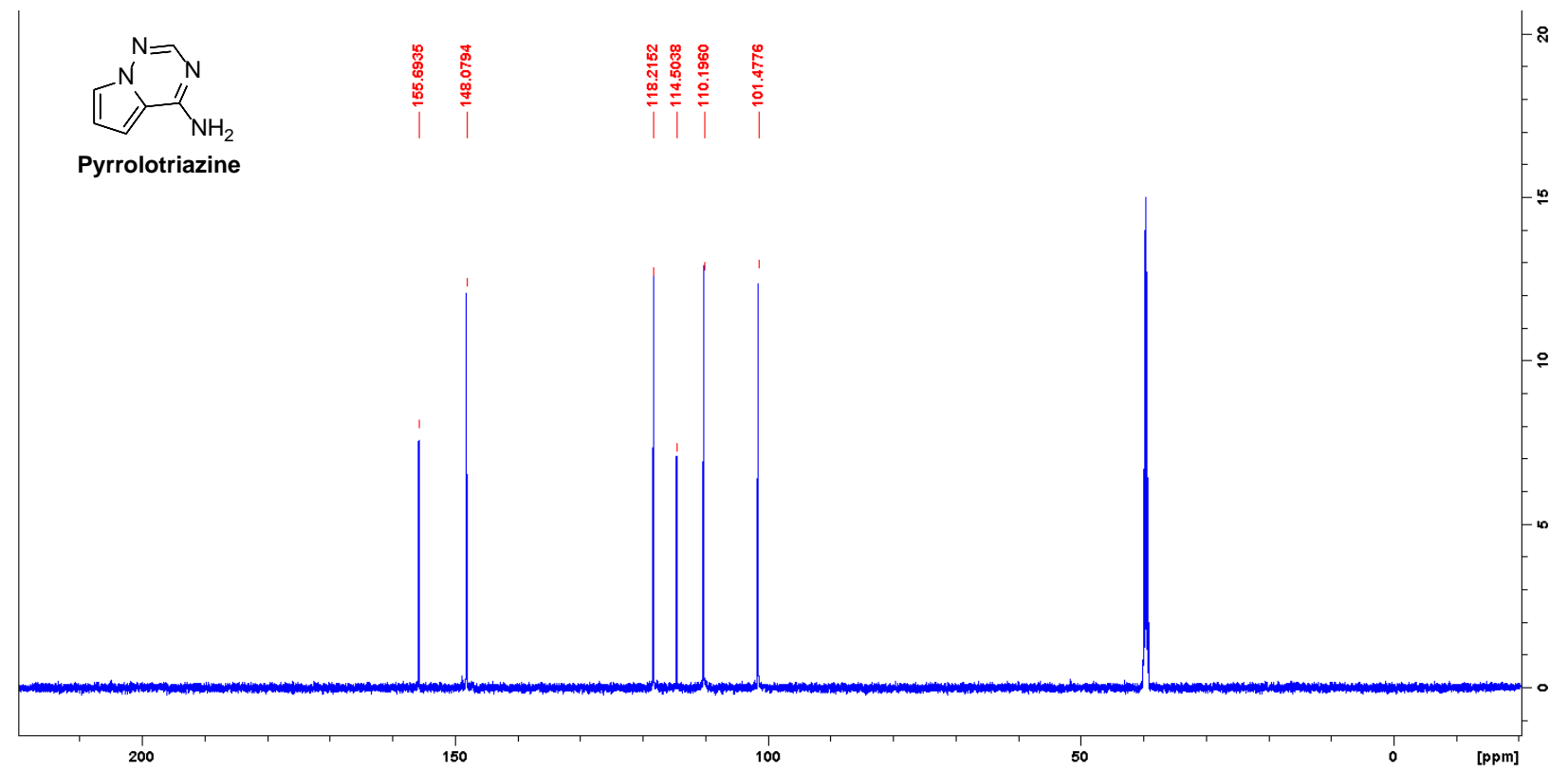




\section{Analytical Method and HPLC chromatogram:}

\section{Structures \& IDs :}

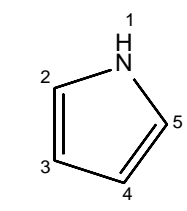

$1 H_{\text {-pyrrole }}$ Exact Mass: 67.04 predicted pka $=17.0$

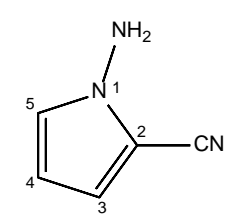

1-amino-2-cyanopyrrole Exact Mass: 107.05

predicted pka $=-4.62$<smiles>O=Cc1ccc[nH]1</smiles>

$1 H_{\text {-pyrrole-2-carbaldehyde }}$ Exact Mass: 95.04

predicted pka $=15.2$

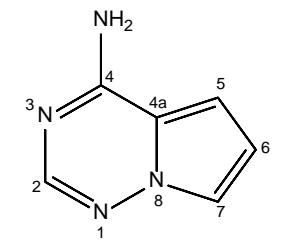

pyrrolo[2,1-f][1,2,4]triazin-4-amine Exact Mass: 134.06

predicted $\mathrm{pka}=4.28$

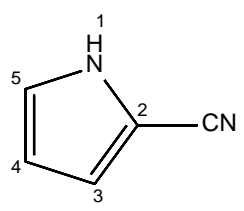

2-cyanopyrrole Exact Mass: 92.04

predicted pka $=14.18$

\section{Conditions}

Mobile Phase A: $5 \mathrm{mM} \mathrm{KH}_{2} \mathrm{PO}_{4}$ in Water, $\mathrm{pH} \sim 5.0$

(0.680g HPLC grade $\mathrm{KH}_{2} \mathrm{PO}_{4}$ in $1000 \mathrm{~mL}$ HPLC grade water)

Mobile Phase B: Acetonitrile

Flow rate: $1.5 \mathrm{~mL} / \mathrm{min}$

Injection volume: $1 \mu \mathrm{L}$

Column: Agilent Zorbax Eclipse C18 (4.6 x 100 mm; $3.5 \mu \mathrm{m})$

Column temp: $30^{\circ} \mathrm{C}$

Isocratic Table

\begin{tabular}{|c|c|c|}
\hline $\begin{array}{l}\text { Time } \\
\text { (min) }\end{array}$ & $\begin{array}{l}\% \\
\mathrm{~A}\end{array}$ & $\% B$ \\
\hline \multirow[t]{2}{*}{0} & 80 & 20 \\
\hline & $\%$ & $\%$ \\
\hline \multirow[t]{2}{*}{4.0} & 80 & 20 \\
\hline & $\%$ & $\%$ \\
\hline
\end{tabular}

Detector wavelength: $230 \mathrm{~nm}$ (Pyrrole to Carbaldehyde), $260 \mathrm{~nm}$

(Carbaldehyde to Triazine)

Post-run equilibration: Off

Sample preparation: Prepare samples at approximately $1.0 \mathrm{mg} / \mathrm{mL}$ in $\mathrm{MeOH}$ (preferred).

\section{Retention Times}

\section{Compound}

Pyrrolo[2,1-f][1,2,4]triazin-4-amine

1H-Pyrrole-2-Carbaldehyde

1-Amino-2-Cyanopyrrole

Pyrrole

2-Cyanopyrrole
Time (min)

$1.301 \mathrm{~min}$

$1.542 \mathrm{~min}$

$1.894 \mathrm{~min}$

$2.052 \mathrm{~min}$

$2.961 \mathrm{~min}$ 
Representative Chromatogram(s) (attach additional chromatograms and spectra as needed)
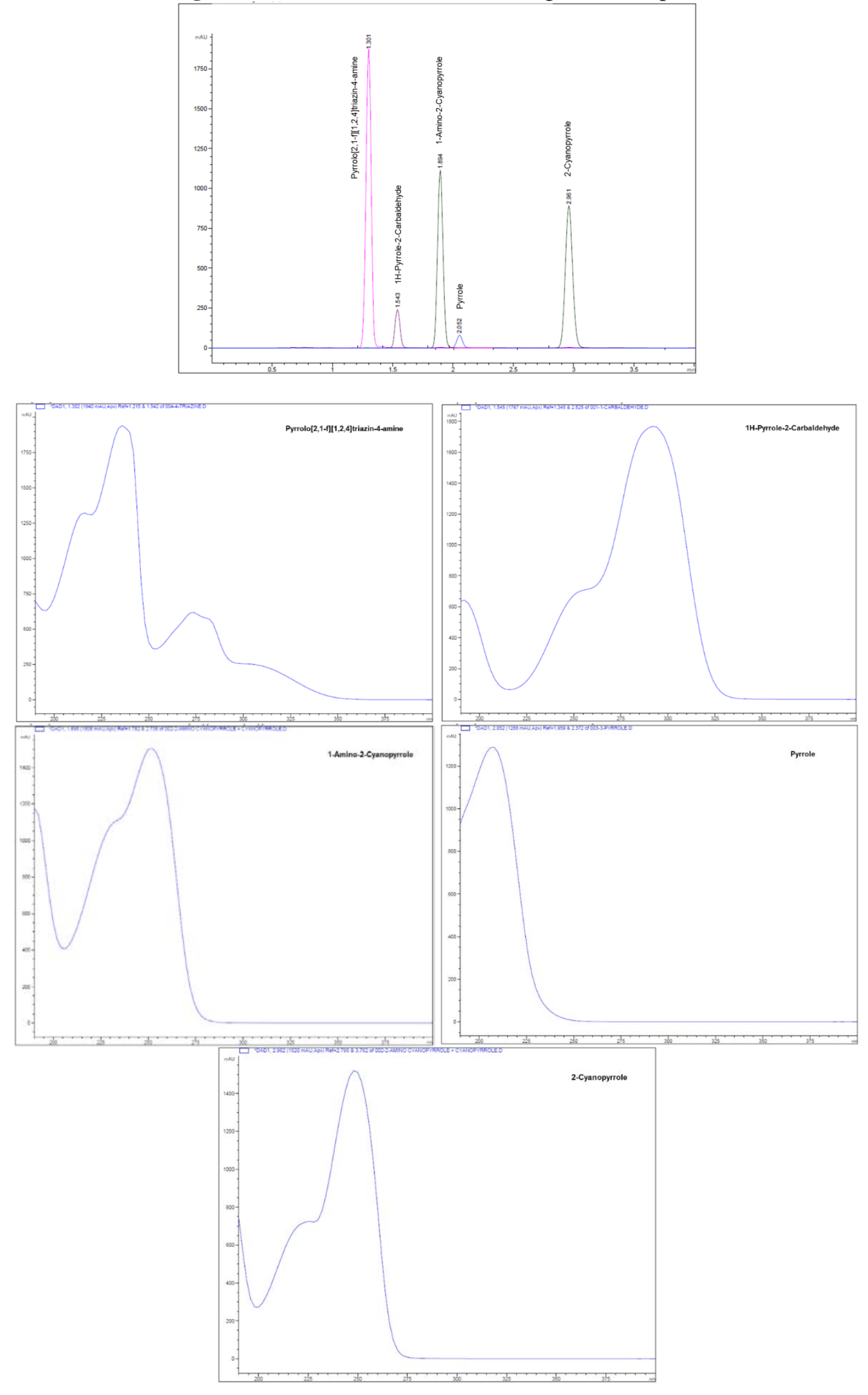


\section{$\underline{\text { References }}$}

1) Xi, N.; Li, M.; Hu, H.; Dai, W.; Li, X.; Wang, T.; Wu, Y. WO 2016/190847A1, 2016.

2) Patil, S. A.; Otter, B. A.; Klein, R. S. J. Het. Chem., 1994, 31, 781-786.

3) Jaffari, G. A.; Nunn, A. J. J. Chem. Soc. C, 1971, 823-826.

4) Hynes, J.; Doubleday, W. W.; Dyckman, A. J.; Godfrey, J. D.; Grosso, J. A.; Kiau, S.; Leftheris, K. J. Org. Chem., 2004, 69, 1368-1371.

5) Verghese, J.; Kong, C. J.; Rivalti, D.; Yu, E. C.; Krack, R.; Alcazar, J.; Manley, J. B.; McQuade, D. T.; Ahmad, S.; Belecki, K.; Gupton, B. F. Green Chem. 2017, 19, 2986-2991. 